\title{
Organization of the Orexin/Hypocretin System in the Brain of Holostean Fishes: Assessment of Possible Relationships with Monoamines and Neuropeptide Y
}

\author{
Daniel Lozano Agustín González Jesús M. López \\ Department of Cell Biology, Faculty of Biology, University Complutense, Madrid, Spain
}

\section{Keywords}

Orexins · Tyrosine hydroxylase · Serotonin .

Immunohistochemistry - Hypothalamus - Lepisosteus · Amia . Brain evolution

\begin{abstract}
Holosteans form a small group of actinopterygian fishes considered the sister group of teleosts. Despite this proximity to the biggest group of vertebrates, relatively few studies have been conducted to investigate the organization of the central nervous system of this group of fishes. In this study, the neuroanatomical distribution of orexin/hypocretin-like immunoreactive (OX-ir) cell bodies and fibers was analyzed in the brain of 3 representative species of the 2 orders of extant holosteans, the spotted gar Lepisosteus oculatus, the Florida gar Lepisosteus platyrhincus, and the bowfin Amia calva. Antibodies against orexin- $A(O X A)$ and orexin-B (OXB) were used, which labeled the same cells and fibers throughout the brain. In addition, double immunohistofluorescence was performed for the simultaneous detection of OXA and OXB with tyrosine hydroxylase, serotonin, and neuropeptide $Y$ (NPY), in an attempt to localize the orexinergic structures precisely and study the possible interactions between these
\end{abstract}

neuroactive substances. The pattern of distribution of OX-ir cells in the 3 species was largely similar, showing labeled cells in the preoptic area (POA), and the tuberal and retrotuberal hypothalamic regions, with only subtle differences between species in the density of labeled cells. OX-ir fibers were found in all main brain subdivisions of the 3 species, mostly in the ventral subpallial areas, POA, hypothalamus, posterior tubercle, thalamus, and mesencephalic tectum. Different densities of orexinergic fibers were observed in relation to catecholaminergic and serotoninergic cell groups, as well as an absence of colocalization between orexins and NPY in the same hypothalamic neurons. The comparison of these results with those obtained in other vertebrates highlights a constant pattern of distribution of this system of neurotransmission among different groups of actinopterygian fishes, especially in teleosts. Conserved features shared by all vertebrates studied were also observed, such as the presence of OX-ir cells in the basal hypothalamus, reflecting the preserved functions of these neuropeptides over the course of evolution.

(c) 2018 S. Karger AG, Basel

Dr. A. González is a member of the J.B. Johnston Club for Evolutionary Neuroscience and the Editorial Board of BBE.

\section{KARGER}

(c) 2018 S. Karger AG, Basel

E-Mail karger@karger.com

www.karger.com/bbe
Dr. Jesús M. López

Departamento de Biología Celular

Facultad de Biología, Universidad Complutense

ES-28040 Madrid (Spain)

E-Mail jmlredondo@bio.ucm.es 


\begin{tabular}{|c|c|c|c|}
\hline A.c. & Amia calva & $\mathrm{PB}$ & phosphate buffer \\
\hline $\mathrm{ac}$ & anterior commissure & $\mathrm{pc}$ & posterior commissure \\
\hline $\mathrm{aCb}$ & cerebellar auricle & POA & preoptic area \\
\hline $\mathrm{cCb}$ & crista cerebellaris & PT & pretectum \\
\hline $\mathrm{cc}$ & central canal & $\mathrm{PVO}$ & paraventricular organ \\
\hline $\mathrm{Cg}$ & central gray & Rai & inferior raphe nucleus \\
\hline Dc & central zone of the dorsal telencephalic area & Ram & median raphe nucleus \\
\hline $\mathrm{dh}$ & dorsal horn of spinal cord & $\mathrm{Ri}$ & inferior reticular nucleus \\
\hline $\mathrm{Dl}$ & lateral zone of the dorsal telencephalic area & $\mathrm{RM}$ & retromamillary region \\
\hline Dld & dorsolateral zone of the dorsal telencephalic area & $\mathrm{Rm}$ & median reticular nucleus \\
\hline Dlv & ventrolateral zone of the dorsal telencephalic area & Rs & superior reticular nucleus \\
\hline $\mathrm{Dm}$ & medial zone of the dorsal telencephalic area & $\mathrm{RTu}$ & retrotuberal hypothalamus \\
\hline $\mathrm{Dp}$ & posterior zone of the dorsal telencephalic area & $\mathrm{sac}$ & stratum album centrale of mesencephalic tectum \\
\hline $5-\mathrm{HT}$ & serotonin & $\mathrm{sm}$ & molecular layer of the cerebellum \\
\hline Hyp & hypophysis & so & spino-occipital motor nucleus \\
\hline igl & internal granular layer & sol & solitary tract \\
\hline inf & infundibulum & spv & periventricular layer of the mesencephalic tectum \\
\hline Ip & interpeduncular nucleus & Tegm & tegmentum \\
\hline Ipn & interpeduncular neuropile & $\mathrm{TH}$ & tyrosine hydroxylase \\
\hline Is & isthmic nucleus & $\mathrm{Th}$ & thalamus \\
\hline LC & locus coeruleus & $\mathrm{Tl}$ & torus longitudinalis \\
\hline LDT & laterodorsal tegmental nucleus & to & optic tract \\
\hline L.o. & Lepisosteus oculatus & Tor & torus semicircularis \\
\hline L.p. & Lepisosteus platyrhincus & Torl & torus lateralis \\
\hline LF & lateral funiculus & $\mathrm{TP}$ & nucleus of the posterior tuberculum \\
\hline Nsol & nucleus of the solitary tract & & telencephalic area \\
\hline nII & optic nerve & $\mathrm{Vv}$ & ventral nucleus of the ventral telencephalic area \\
\hline nVIII & octaval nerve & VF & ventral funiculus \\
\hline $\mathrm{ob}$ & olfactory bulb & III & oculomotor nucleus \\
\hline oc & optic chiasm & IV & trochlear nucleus \\
\hline OT & optic tectum & $\mathrm{Vm}$ & trigeminal motor nucleus \\
\hline OX-ir & orexin-immunoreactive & VIIIa & anterior octaval zone \\
\hline OXA/OXB & orexin-A/orexin-B & VIIIi & intermediate octaval zone \\
\hline $\mathrm{Pa}$ & paraventricular region & $\mathrm{IXm}$ & glossopharyngeal motor nucleus \\
\hline PAP & peroxidase antiperoxidase & $\mathrm{Xm}$ & vagal motor nucleus \\
\hline
\end{tabular}




\section{Introduction}

Within extant vertebrates, the group Osteichthyes (bony vertebrates) is formed by the ray-finned fishes (actinopterygians) and the lobe-finned fishes (sarcopterygians), 2 large groups that diverged in the mid-Silurian, about 425 million years ago. The lobe-finned fishes separated in the early Devonian (approx. 400 million years ago) into coelacanths, lungfishes, and tetrapods. At about the same time, actinopterygians gave rise to the basal group of polypteriforms (Cladistia), and another basal group that diverged only later into chondrosteans and 2 groups of neopterygian fishes, the teleosts and the holosteans [Broughton et al., 2013]. With $>30,000$ species, teleosts are by far the most successful group of aquatic vertebrates whereas holosteans are a small group constituted by 2 orders: Lepisosteiformes, commonly known as gars, which includes 2 genera, Atractosteus ( 3 species) and Lepisosteus ( 4 species), and Amiiformes, known as bowfins, with a single living species, Amia calva [Nelson, 2006]. Based on the analysis of multiple nuclear gene sequences [Near et al., 2012], whole-genome duplication events [Pasquier et al., 2016], and phylotranscriptomics [Irisarri et al., 2017], holosteans are now regarded as a monophyletic sister group of teleosts. These data are consistent with traditional morphologically based inferences [Stiassny et al., 2004] and previous neuroanatomical studies [Nieuwenhuys, 1967, 2011; Nieuwenhuys and Meek, 1990]. Given the large diversification of teleosts, variation in brain region proportions and adaptations is not surprising [Meek and Nieuwenhuys, 1998]. Therefore, because teleosts exhibit many evolutionary novelties, understanding the ancestral condition of neopterygians appears easier by analyzing and resolving particular traits in the sister group of holosteans.

Despite the evolutionary importance of holosteans, there is little information about their neuronatomy, in contrast to the extensive experimental data about the organization of the nervous system of teleosts [Meek and Nieuwenhuys, 1998]. In particular, modern approaches such as tract-tracing and immunohistochemical techniques were used in several studies related to the visual and lateral-line systems [Northcutt and Butler, 1976, 1980; McCormick, 1981; Song and Northcutt, 1991a, 1991b; Butler and Northcutt, 1992; Collin and Northcutt, 1995] and some neurotransmitter systems [Parent and Northcutt, 1982; Chiba and Oka, 1999; Malz et al., 1999; Baker and Bird, 2002; Chiba, 2005].

Among the numerous neurotransmitters that characterize specific brain systems, orexins (hypocretins) are well conserved across vertebrates, and so studies of orexinergic cells and fibers in the brain have been carried out in representatives of most vertebrate groups (see below). Orexin-A (OXA) and OXB (hypocretins 1 and 2, respectively) are 2 neuropeptides that belong to the incretin peptide superfamily and are derived from the common precursor prepro-orexin [de Lecea et al., 1998; Sakurai et al., 1998; Alvarez and Sutcliffe, 2002]. In mammals, only a few hypothalamic cell populations contain orexin-producing neurons, which show extensive projections to most brain regions [de Lecea et al., 1998; Peyron et al., 1998; Cutler et al., 1999; Nambu et al., 1999; McGranaghan and Piggins, 2001; Mintz et al., 2001; Zhang et al., 2001, 2004; Ferguson and Samson, 2003; Kirouac et al., 2005; Nixon and Smale, 2007; Kruger et al., 2010; Bhagwandin et al., 2011a, 2011b; Gravett et al., 2011; Dell et al., 2012, 2013]. This may explain the diversity of the brain functions of these peptides, such as regulation of food intake, reproduction, the sleep-wake cycle, cardiovascular control, and thermoregulation [Hoskins et al., 2008; Teske et al., 2010; Sakurai and Mieda, 2011; Volkoff, 2012].

Due to the conserved molecular structure of orexins [Ohkubo et al., 2002; Shibata et al., 2008; Wong et al., 2011], it is possible to localize orexin-like immunoreactive (OX-ir) cells and fibers in the brains of nonmammal vertebrates by using antibodies against mammalian orexins. The distribution of orexins in the brain has been reported in birds [Ohkubo et al., 2002; Singletary et al., 2006; Miranda et al., 2013], reptiles [Domínguez et al., 2010], amphibians [Shibahara et al., 1999; Galas et al., 2001; López et al., 2009b, 2016], and lungfishes [López et al., 2009a]. In the case of teleosts, there are many studies regarding the orexinergic system [Kaslin et al., 2004; Huesa et al., 2005; Amiya et al., 2007; Panula, 2010; Matsuda et al., 2012; Pérez Sirkin et al., 2013] and its functions [Volkoff et al., 2005; Matsuda et al., 2012; Volkoff, 2012; Chiu and Prober, 2013; Nisembaum et al., 2014; Shahjahan et al., 2014], which were demonstrated to be basically comparable to those in mammals. In a previous study, we reported the distribution of the OX-ir cells and fibers in the brain of cladistians, in an attempt to highlight shared primitive features of this system in ray-finned fishes [López et al., 2014]. Surprisingly, the orexinergic system has not been previously addressed in holosteans.

Given the phylogenetic importance of holosteans as the sister group of teleosts, in our laboratory we have a line of research into holosteans that aims to clarify the neuroanatomical features that aid in the understanding of the basic condition of neopterygians and enable comparisons with more primitive actinopterygians, such as 
cladistians. We have described the cholinergic [Morona et al., 2013] and nitrergic systems [López et al., 2017] and some transcription factors in the subpallium of holosteans [González et al., 2014]. Following this research, we have conducted this study to provide detailed information about the location of OX-ir cells and fibers in the brain of 3 representative species of holosteans: the spotted gar (Lepisosteus oculatus), the Florida gar (L. platyrhincus), and the bowfin (A. calva). We carried out immunohistochemical studies with the same methodology previously used in the brain of several tetrapods [López et al., 2009a, 2016; Domínguez et al., 2010], lungfishes [López et al., 2009b], and cladistians [López et al., 2014]; this reinforces the reliability of results and facilitates their comparison across vertebrates.

In addition, we investigated, by means of double-labeling experiments, the possible colocalization/codistribution of orexins with tyrosine hydroxylase $\mathrm{TH}$; the first and rate-limiting enzyme in the synthesis of catecholamines), serotonin (5-HT), and neuropeptide Y (NPY). These experiments were prompted by previous studies on tetrapods and fishes, which reported interactions with some catecholaminergic groups in the brainstem, serotoninergic cells in the raphe nuclei [Peyron et al., 1998; Baldo et al., 2003; Wang et al., 2003; Kaslin et al., 2004; Zhang et al., 2004; Balcita-Pedicino and Sesack, 2007; López et al., 2009a, 2009b, 2014, 2016; Domínguez et al., 2010; Panula, 2010], and NPY elements in the hypothalamus [Volkoff, 2006; López et al., 2014].

Finally, as in our previous studies of holosteans, our comparative analysis was framed within the current neuromeric model of the brain regionalization that has now been validated for most vertebrates (forebrain: Puelles and Rubenstein [2003, 2015]; brainstem: Gilland and Baker [1993]; Aroca and Puelles [2005]; Straka et al. [2006]).

\section{Materials and Methods}

Eighteen young adult gars, $9-16 \mathrm{~cm}$ in length (11 spotted gars, L. oculatus, and 7 Florida gars, L. platyrhincus), and 3 adult bowfins, A. calva, $28-35 \mathrm{~cm}$ in length, were used. The animals were obtained from licensed suppliers (PezyCia, Madrid, Spain) and maintained in aquaria with a controlled temperature $\left(24-28^{\circ} \mathrm{C}\right)$ and natural light conditions. Although the sex of each animal was not determined, it was established that both males and females were studied. The original research reported here was performed according to the regulations and laws established by the European Union (2010/63/EU) and Spain (Royal Decree 53/2013) for the care and handling of animals in research, and after approval from the Complutense University to conduct the experiments described.
The animals were deeply anesthetized by immersion in $0.1-$ $0.2 \%$ tricaine methanesulfonate solution (MS222, pH 7.3; Sandoz, Basel, Switzerland), and perfused transcardially with physiological saline, followed by $100-150 \mathrm{~mL}$ of cold $4 \%$ paraformaldehyde in $0.1-\mathrm{M}$ phosphate buffer ( $\mathrm{PB} ; \mathrm{pH} 7.4$ ). The brain and upper spinal cord were removed and kept in the same fixative for 2-3 h. Subsequently, they were immersed in a solution of $30 \%$ sucrose in $\mathrm{PB}$ for $4-6 \mathrm{~h}$ at $4{ }^{\circ} \mathrm{C}$ until they sank, and were then embedded in a solution of $20 \%$ gelatin with $30 \%$ sucrose in PB, and stored for $6 \mathrm{~h}$ in a $10 \%$ formaldehyde solution at $4{ }^{\circ} \mathrm{C}$. The brains were cut on a freezing microtome $(30-40 \mu \mathrm{m})$ on the transverse or sagittal plane, and sections were collected and rinsed in cold PB.

\section{Orexin Immunohistochemistry}

The free-floating sections were rinsed twice in $\mathrm{PB}$, treated with $1 \% \mathrm{H}_{2} \mathrm{O}_{2}$ in $\mathrm{PB}$ for $20 \mathrm{~min}$ to reduce endogenous peroxidase activity, rinsed again 3 times in $\mathrm{PB}$, and processed by the peroxidase antiperoxidase (PAP) method [Sternberger, 1979]. This included a first incubation of the sections in a primary goat anti-OXA serum (Santa Cruz Biotechnology, Santa Cruz, CA, USA; code sc-8070) or goat anti-OXB serum (Santa Cruz Biotechnology; code sc8071 ), diluted $1: 500$ in $\mathrm{PB}$ containing $0.5 \%$ Triton $\mathrm{X}-100,15 \%$ normal rabbit serum, and $2 \%$ bovine serum albumin, for $48 \mathrm{~h}$ at $4{ }^{\circ} \mathrm{C}$. Subsequently, the sections were rinsed 3 times in PB for $10 \mathrm{~min}$ and incubated for $60 \mathrm{~min}$ at room temperature in rabbit anti-goat serum (Merck-Millipore, Darmstadt, Germany) diluted 1:50. After rinsing again 3 times in $\mathrm{PB}$ for $10 \mathrm{~min}$, the sections were incubated for 90 min in goat PAP complex (diluted 1:500; Merck-Millipore). Secondary antiserum and PAP complex were diluted in $\mathrm{PB}$ containing $0.5 \%$ Triton $\mathrm{X}-100,15 \%$ normal rabbit serum and $2 \%$ bovine serum albumin. Finally, the sections were rinsed three times for $10 \mathrm{~min}$ in $\mathrm{PB}$, and subsequently developed for 3-6 min in $0.5 \mathrm{mg} / \mathrm{mL} \mathrm{DAB}$ (Vector SK4100) intensified with nickel [Adams, 1981], with $0.01 \% \mathrm{H}_{2} \mathrm{O}_{2}$ in $\mathrm{PB}$. Transverse and sagittal series were mounted on glass slides (mounting medium: $0.25 \%$ gelatin in $0.1 \mathrm{M}$ Tris-HCl buffer, $\mathrm{pH}$ 7.6) and, after dehydration, coverslipped with Entellan (Merck, Darmstadt, Germany). Some sections were counterstained with cresyl violet to facilitate the analysis of the results.

The specificity of the immunohistochemical reaction was corroborated with controls that included: (1) staining some selected sections with preimmune goat serum; (2) controls in which either the primary antibody, secondary antibody or the PAP complex was omitted; (3) homologous and heterologous preabsorptions of the primary antibody with synthetic blocking peptides for OXA or OXB (both from Santa Cruz Biotechnology; codes sc-8070P and sc- $8071 \mathrm{P}$ respectively; $0.1,1.0$, or $10 \mu \mathrm{M})$. In all these negative controls, the immunostaining was eliminated, even when the goat anti-OXA or goat anti-OXB was preabsorbed with the blocking peptides at a low concentration $(0.1 \mu \mathrm{M})$.

\section{Double Orexin and NPY, TH, or 5-HT Immunolabeling}

A procedure based on immunohistofluorescence was used as follows: (1) a first incubation for $72 \mathrm{~h}$ at $4{ }^{\circ} \mathrm{C}$ in a mixture of goat anti-OXA or goat anti-OXB (diluted 1:500) and rabbit anti-NPY (diluted 1:1,000; gift from Dr. J.D. Mikkelsen, University of Copenhagen, Denmark), mouse anti-TH (diluted 1:1,000; Immunostar, USA; code P22941), or rabbit anti-5-HT (diluted 1:1,000; Immunostar, USA; code 20080), and (2) a second incubation for 90 $\mathrm{min}$ at room temperature in a mixture of secondary antisera: don- 


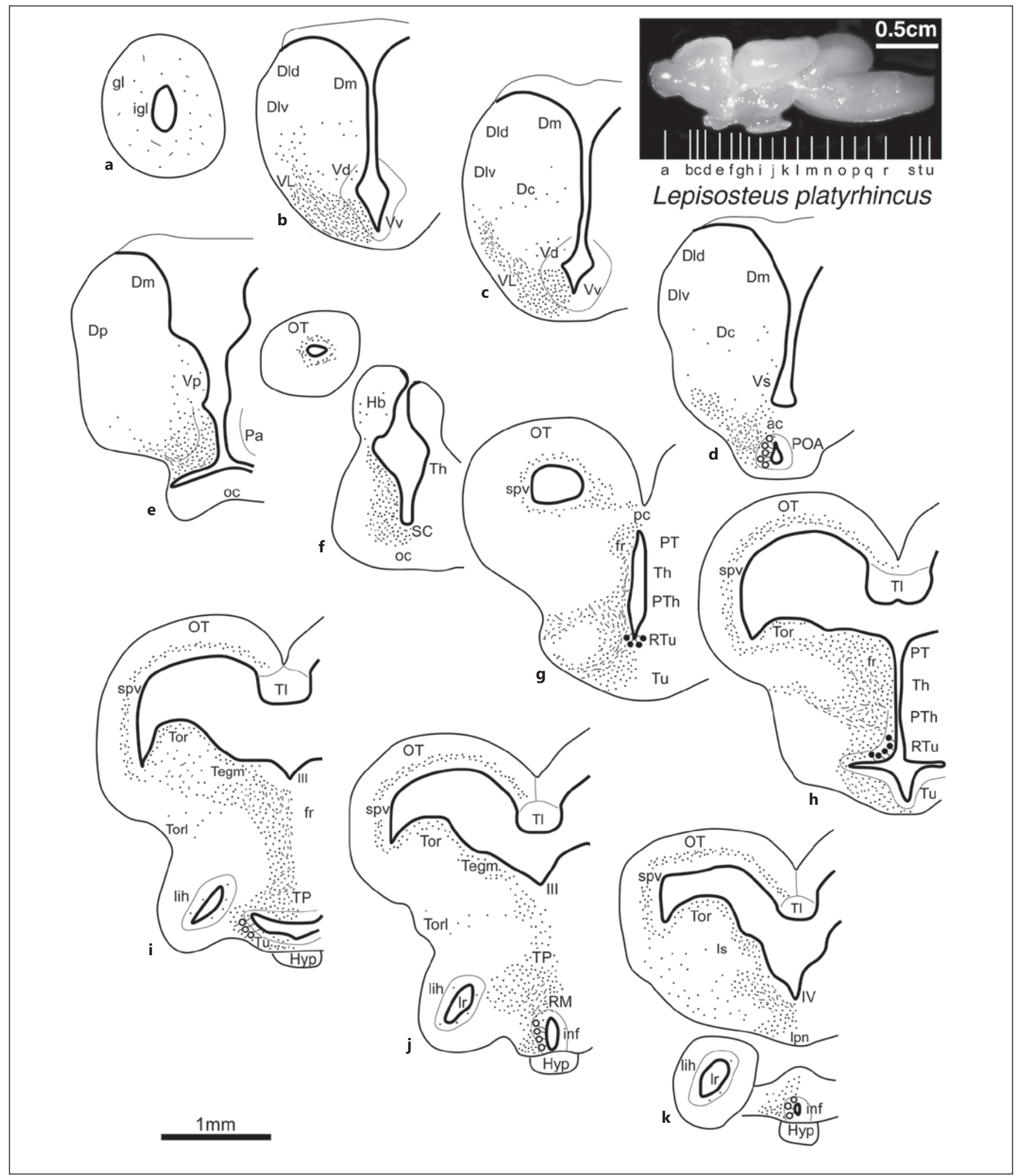

Fig. 1. a-u Diagrams of transverse sections through the brain of L. platyrhincus at the levels indicated in the lateral view of the brain. OX-ir cell bodies (large dots) and fibers (small dots, wavy lines) are represented in the left half of each section. Faintly labeled cells are drawn empty. For abbreviations, see list.

(Figure continued on next page.) 


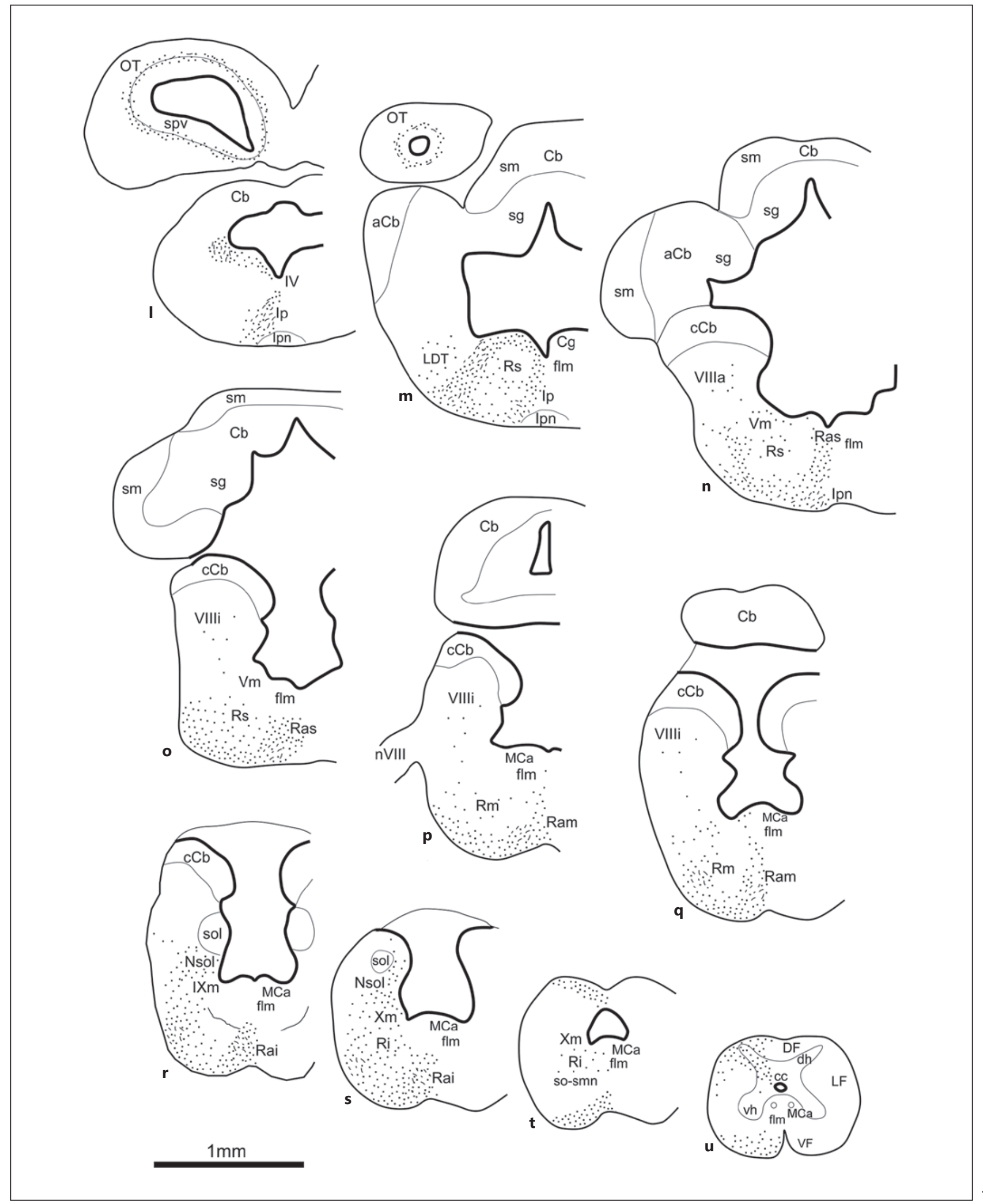


key anti-goat Alexa 594 (red fluorescence; diluted 1:300; Molecular Probes, Denmark) and FITC-conjugated chicken anti-rabbit (green fluorescence; diluted 1:100; Merck-Millipore) or chicken anti-mouse Alexa 488 (green fluorescence; diluted 1:300; Molecular Probes). After rinsing 3 times in $\mathrm{PB}$, the sections were mounted on glass slides and coverslipped with UltraCruz ${ }^{\mathrm{TM}}$ mounting medium containing DAPI for fluorescence labeling of DNA (Santa Cruz Biotechnology, sc-24941). The specificity of the TH and 5-HT antisera has been previously described [Morona et al., 2013; González et al., 2014; López et al., 2017], and the pattern of staining observed for NPY was consistent with that reported for $L$. oculatus [Chiba, 2005].

\section{Evaluation and Presentation of the Results}

The distribution and localization of OX-ir cell bodies and fibers in the brains was carefully analyzed, and the pattern of labeling was charted in representative transverse sections at different brain levels for L. platyrhincus and A. calva (Fig. 1,2). Drawings were made by means of camera lucida in which the sections counterstained with cresyl violet facilitated the interpretation of the localization of the labeled structures. The sections were analyzed with an Olympus BX51 microscope equipped for fluorescence with appropriate filter combinations for the identification of orexins and NPY/ TH/5-HT-ir cells and fibers in the double-labeled sections. Photomicrographs were adjusted for contrast and brightness with Adobe PhotoShop CS4 (Adobe Systems, San José, CA, USA) and were mounted on plates using Canvas 11 (ACS Systems International, Santa Clara, CA, USA). Selected photomicrographs of singlestained sections are presented in Figures 3, 4, and double-stained images are arranged in Figure 5.

The nomenclature is the same used in our previous studies on holosteans [Morona et al., 2013; López et al., 2017], and essentially follows previously used terms in these species [Northcutt, 1982; Parent and Northcutt, 1982; Song and Northcutt, 1991a, 1991b; Butler and Northcutt, 1992; Northcutt and Butler, 1993; Heijdra and Nieuwenhuys, 1994; Collin and Northcutt, 1995; Meek and Nieuwenhuys, 1998; Chiba and Oka, 1999; Baker and Bird, 2002; Chiba, 2005], but incorporates the terminology of the prosomeric model for the forebrain [Puelles and Rubenstein, 2003, 2015].

\section{Results}

Similar patterns of immunoreactivity were revealed with the antibodies against OXA and OXB used in this study and, for each of the 3 species examined, these were constant from animal to animal. Therefore, throughout the text, we will refer to OX-ir structures independently of the antibody used. The labeling observed was restricted to neuronal cell bodies located in specific forebrain groups, whereas fibers were widely distributed in the central nervous system, albeit more densely in the forebrain. The brain distribution of OX-ir cells and fibers in the 3 holostean species is described below, and the main data are summarized in Table 1 (where species variations can be observed). The schematic chartings in Figures 1 and 2 depict the distribution of the labeled cells and fibers for the cases of L. platyrhincus and A. calva, and are meant to help the description, which follows a rostrocaudal organization.

\section{OX-ir Cell Bodies}

The 3 species showed OX-ir neurons at comparable locations, although some differences in cell density were noted (Table 1). Cells in the preoptic area (POA) were the most rostrally located, and were observed close to the ventricular layer (Fig. 1d, 2d, 3c). They were small and rounded with cerebrospinal fluid-contacting (CSF-c) processes that reached the preoptic recess of the third ventricle (Fig. 3c, asterisks). A. calva showed more cells in this area than both Lepisosteus spp. (Table 1). The double-labeling techniques revealed that $\mathrm{OX}$-ir and 5-TH-ir cells do not coexist in the same rostrocaudal levels of the POA, and that OX-ir cells occupy a dorsolateral position in relation to the $\mathrm{TH}$-ir cells, with no coexpression of orexins and TH in the same cells (fig. 5a, a').

Another group of OX-ir cells was located in the retrotuberal area within the basal hypothalamus (RTu), and it extended from the most dorsal to the most ventral levels of this area (rostral to caudal hypothalamic levels in classical transverse sections). This population was the most numerous of the brain, and was formed by conspicuously intense OX-ir cells (Fig. 1g, h, 2g, h, 3f, g, j, $4 a, b, 5 d-i)$. Mainly bipolar cells with long CSF-c processes that reach the ventricle formed this OX-ir population (Fig. 3g, j, 4b, 5e). There were no significant differences in the labeling intensity and the number of OX-ir cells of this group across the 3 species studied, although the number of orexinergic cells was higher at the rostral level (Fig. 3f, g) than at the caudal hypothalamic level where the number of cells was clearly reduced (Fig. $3 \mathrm{~h}$, j). The double-labeling experiments showed that this group was located lateroventral to the paraventricular organ identified by its 5-HT-ir cells close to the ventricle (Fig. 5f, g), and ventromedial to the prethalamic TH-ir cell group from which it was distinctly separated (Fig. 5e, $\mathrm{h}, \mathrm{i})$. The double-staining procedure also showed that a small population of NPY-ir cells in the RTu intermingled with the OX-ir cells only at the rostral hypothalamic level, but actual colocalization of both neuropeptides in the same cells was never observed (Fig. 5d). However, a noticeable NPY-ir innervation of the OX-ir cell groups in the preoptic, retrotuberal, and tuberal hypothalamic regions was observed, and also a moderate OX-ir innervation of the NPY-ir hypothalamic cell population (Fig. 5d, d'). 
The last population of orexinergic neurons was located along the tuberal hypothalamus (Tu) of A. calva (Fig. $2 \mathrm{~h}$, i), and was restricted to the caudal tuberal hypothalamic levels in the case of Lepisosteus (Fig. 1i-k). These faintly OX-ir cells were small and showed bipolar morphology with a short CSF-c process (Fig. 3i) observed close to the ventricle of the infundibulum (Fig. 5k). Comparing the 3 species, L. oculatus had fewer OX-ir cells in the $\mathrm{Tu}$ (Table 1).

\section{OX-ir Fibers}

In the rostral telencephalon of the 3 species studied, sparse OX-ir varicose fibers and terminal-like structures were observed in the olfactory bulbs, located mainly in the internal granular layer (Fig. 1a, 2a, 3a). The pallial areas were poorly innervated by OX-ir fibers (Fig. 1b-e, 2be), being the ventrolateral (Dlv), central (Dc), and medial $(\mathrm{Dm})$ zones of the dorsal telencephalic area, the regions more densely innervated (Fig. 3b, 5b). In contrast, the subpallium of holostean fishes showed a rich orexin innervation (Fig. 1b-e, 2b-d) that was especially relevant on the ventral part of the ventral telencephalic area $(\mathrm{Vv})$ and, to a lesser extent, on the lateral part of the ventral telencephalic area (VL) of fishes of the genus Lepisosteus (Fig. 1b, c, 3b, 5b). Comparatively, the presence of OX-ir fibers and terminal-like structures in the dorsal $(\mathrm{Vd})$, supracommissural (Vs) and posterior $(\mathrm{Vp})$ parts of the ventral telencephalic area of the 3 species was markedly more restricted (Fig. 1b-e, 2b-d, 3b, 5b). The POA, together with the $\mathrm{Vv}$, was the telencephalic zone with more OX-ir fibers (Fig. 1d, 2d), surrounding the preoptic orexinergic cells (Fig. 3c, 5a, a') and laterally separated from the ventricle. Comparatively, L. platyrhincus was the species with the largest number of immunoreactive fibers in this area (Table 1).

In the alar hypothalamus, remarkable OX-ir innervation was observed in the paraventricular and subparaventricular areas (Fig. 1e, f, 2e, f, 3d, e). The latter region, which includes the suprachiasmatic nucleus (SC), was the alar hypothalamic area with the highest density of OX-ir varicose fibers and terminal-like structures, especially in fishes of the genus Lepisosteus (Fig. 3e), some of which crossed the midline through the optic chiasm. In the double-labeling experiments, this prominent orexinergic innervation was observed close to the TH-ir cells of the SC (Fig. 5c). The basal hypothalamus was also widely innervated by $\mathrm{OX}$-ir varicose fibers and terminal-like structures, with the $\mathrm{Tu}, \mathrm{RTu}$, and retromamillary region (RM) being the areas with more innervation in Lepisosteus (Fig. $1 \mathrm{~g}-\mathrm{k}, 2 \mathrm{~g}-\mathrm{I}, 4 \mathrm{a}-\mathrm{c}, 5 \mathrm{~h}, \mathrm{k}$ ) and less conspicuous in $A$. calva (Fig. 3f, h). In contrast, the large inferior hypothalamic lobes were almost devoid of orexinergic innervation (Fig. 1i-k, 2i, j). By means of the double-labeling technique, the OX-ir fibers in the RM were observed intermingled with the prominent $\mathrm{TH}$-ir cell group present in this area (Fig. 5k). Although the median eminence showed orexin innervation, no OX-ir fibers were observed entering the hypophysis (Fig. 1i-k, 2g, i, 5k).

According to the prosomeric model [Puelles and $\mathrm{Ru}-$ benstein, 2003, 2015], in the caudal part of the forebrain, the diencephalon is divided into 3 prosomeres $(\mathrm{p} 1-\mathrm{p} 3$, from caudal to rostral) containing the pretectum ( $\mathrm{p} 1)$, the thalamus (p2; formerly dorsal thalamus), and the prethalamus (p3; formerly ventral thalamus) in their alar plates, and smaller tegmental regions in their basal plates. In the diencephalic alar plate, moderate OX-ir innervation of fine varicose fibers and terminal-like structures was observed mainly in the periventricular region of the 3 prosomeres (Fig. 1f-h, 2f-I, 3e, f, h, j, 4a, 5c', d', e, g', h, i). The asymmetric habenula situated dorsal to the thalamus was reached by a few OX-ir fibers only in the ventral part of both habenulae (Fig. 1f, 2g, 3e). In the basal plate of prosomere 3 , a remarkable innervation of the $\mathrm{TH}$-ir cell group located in the posterior tubercle (Fig. 1i, j, 2i, 4c, 5j) was observed, especially in the 2 Lepisosteus spp. (Table 1).

In the dorsal mesencephalon, moderate OX-ir innervation was found in deep and intermediate layers of the optic tectum along its rostrocaudal extent (Fig. 1g-m, 2h$\mathrm{m})$, whereas the superficial layers were almost devoid of immunoreactive fibers. These varicose fibers and terminal-like structures were located in the outer zone of the stratum griseum periventriculare and in the stratum album centrale (after Meek and Nieuwenhuys, 1998; Fig. 4a, d, 5d', l'). In all 3 species, moderate distribution of OX-ir fibers was also observed primarily in the periventricular region of the torus semicircularis and the mesencephalic tegmentum (Fig. 1h-k, 2j-1, 4d, 5l'). The torus lateralis of holosteans showed a few OX-ir varicose fibers (Fig. 1i, j, $2 j-1$ ) whereas the torus longitudinalis was devoid of orexinergic fibers (Fig. 1h-k, 2i-1 4a).

In general, the pattern of orexinergic innervation observed in the hindbrain was reduced compared to other

Fig. 2. a-u Diagrams of transverse sections through the brain of A. calva at the levels indicated in the lateral view of the brain. OXir cell bodies (large dots) and fibers (small dots, wavy lines) are represented in the left half of each section. Faintly labeled cells are drawn empty. For abbreviations, see list.

(For figure see next pages.) 


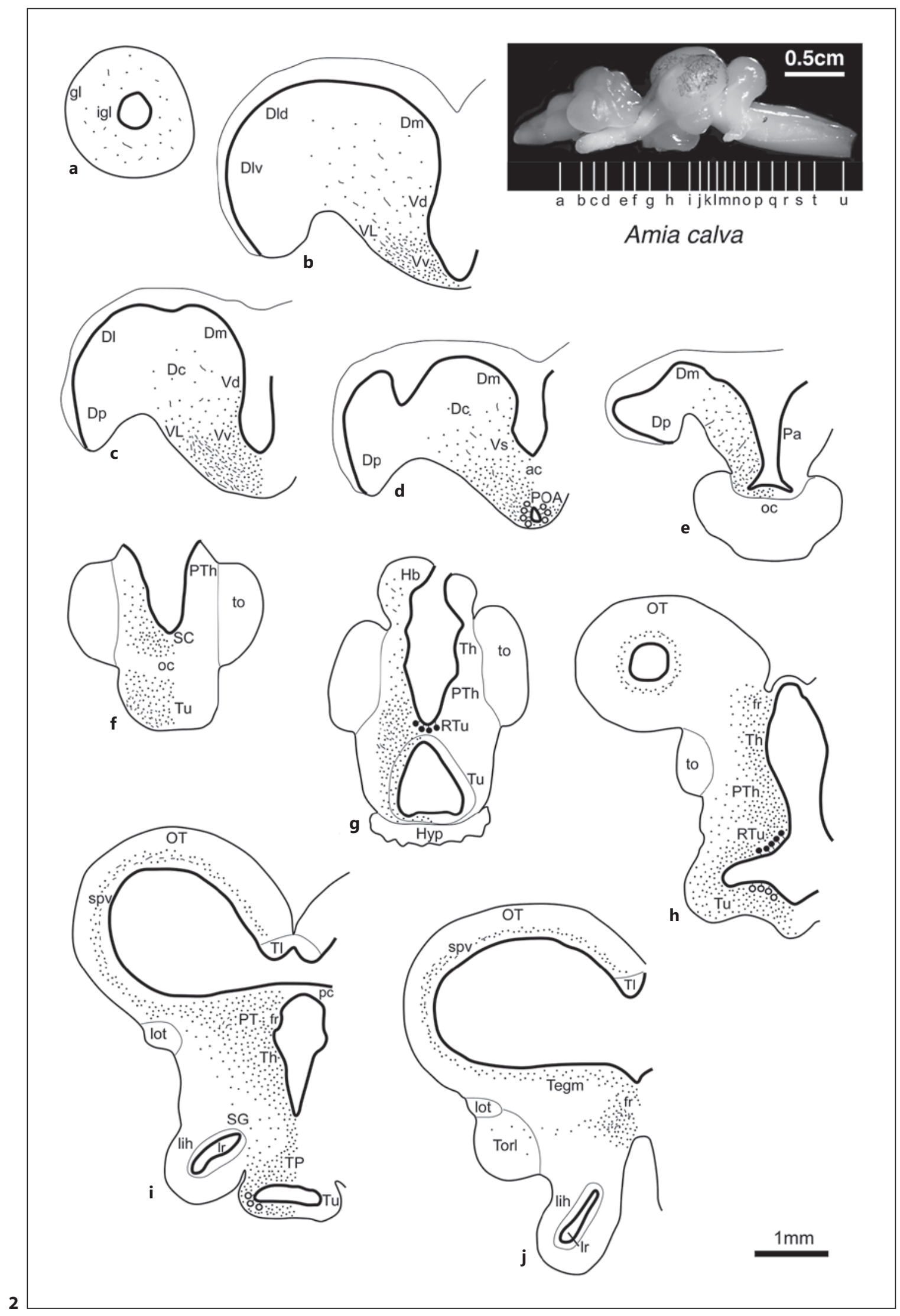




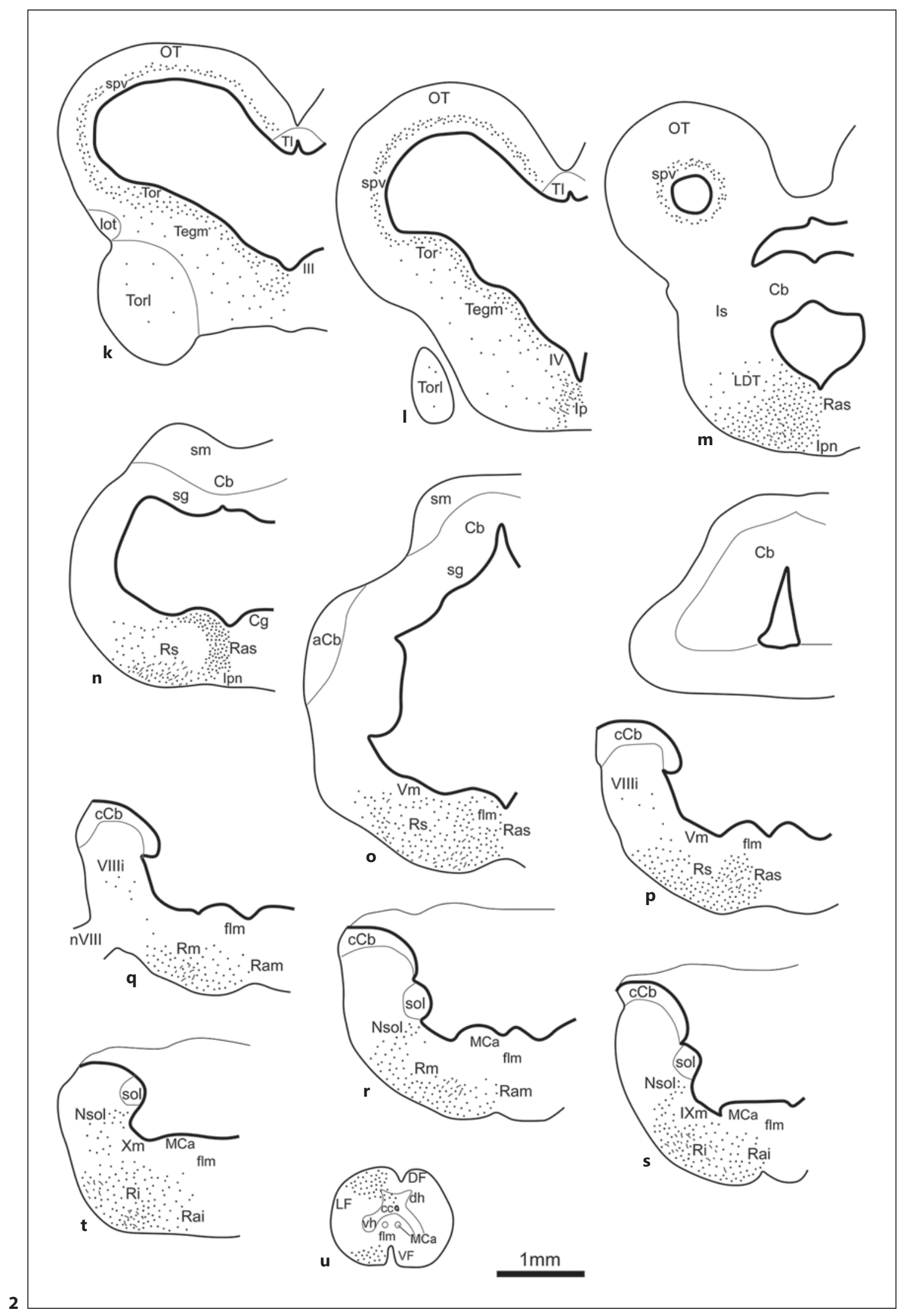



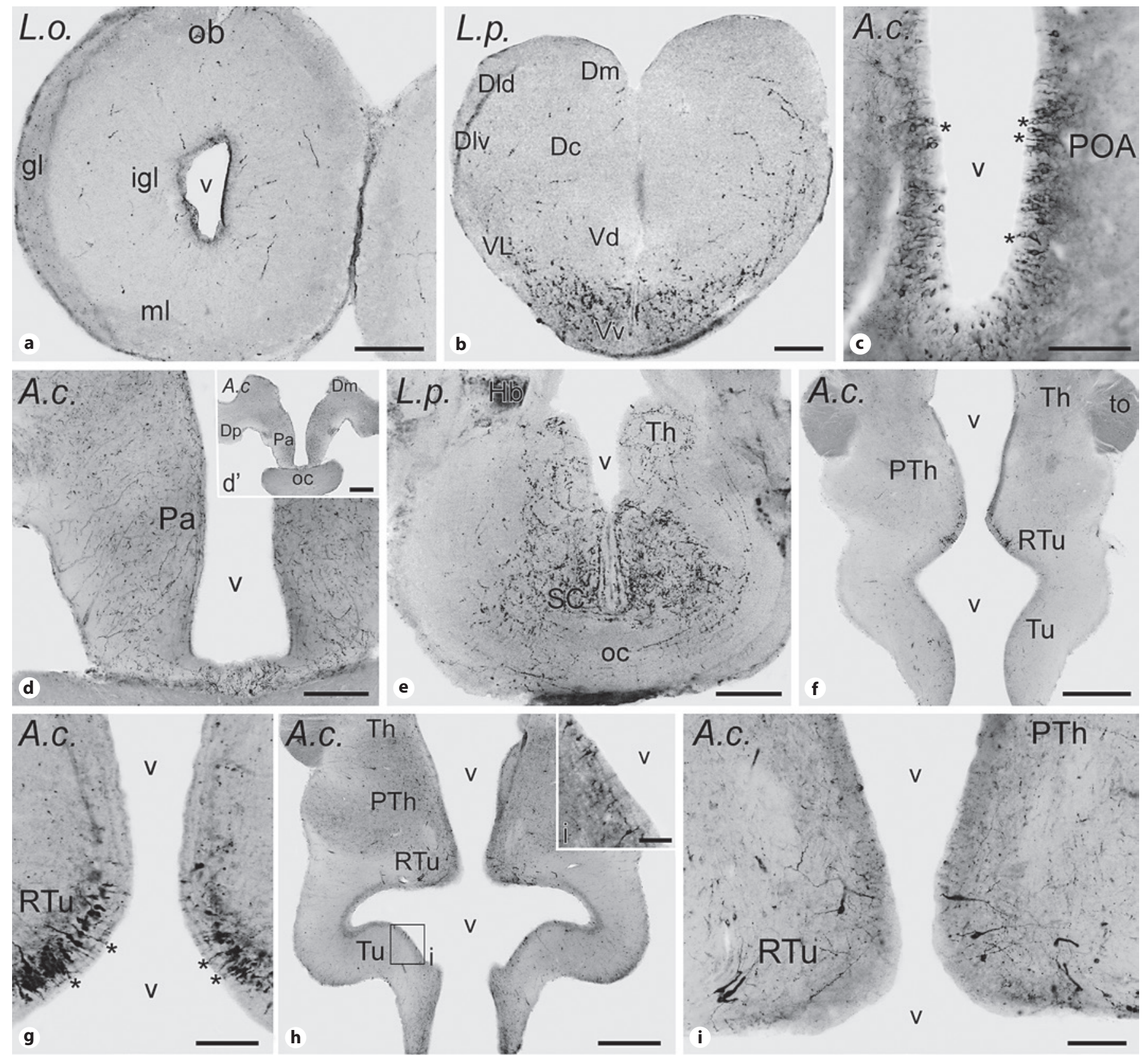

Fig. 3. Photomicrographs of transverse sections through the forebrain of L. platyrhincus (L.p.), L. oculatus (L.o.), and A. calva (A.c.; indicated in the upper left corner of each photomicrograph) illustrating OX-ir cell bodies and fibers in the olfactory bulb (a), pallial and subpallial areas (b), preoptic area (c, asterisks indicate CSF-contacting cell processes), paraventricular hypothalamic area ( $\mathbf{d}$ is a higher magnification of $\mathbf{d}^{\prime}$ ), suprachiasmatic nucleus and thalamus (e), and tuberal and retrotuberal hypothalamic areas from rostral (f, $\mathbf{g}$ [asterisks in $\mathbf{g}$ indicate the CSF-contacting cell processes]) to caudal levels $(\mathbf{h}, \mathbf{j})$. The higher magnification in $\mathbf{i}$ shows a detail of faintly OX-ir cells of tuberal hypothalamus. Photographs $\mathbf{a}, \mathbf{b}$, and $\mathbf{e}$ correspond to levels $\mathbf{a}, \mathbf{b}$, and $\mathbf{f}$ of Figure 1, whereas photographs $\mathbf{c}, \mathbf{d}$, and $\mathbf{f}-\mathbf{j}$ correspond to levels $\mathbf{d}, \mathbf{e}$, and $\mathbf{h}$ of Figure 2. For abbreviations, see list. Scale bar, $500 \mu \mathrm{m}\left(\mathbf{d}^{\prime}, \mathbf{f}\right.$, h); $200 \mu \mathrm{m}(\mathbf{a}, \mathbf{b}, \mathbf{d}, \mathbf{e}) ; 100 \mu \mathrm{m}(\mathbf{c}, \mathbf{g}, \mathbf{j}) ; 50 \mu \mathrm{m}(\mathbf{i})$. 

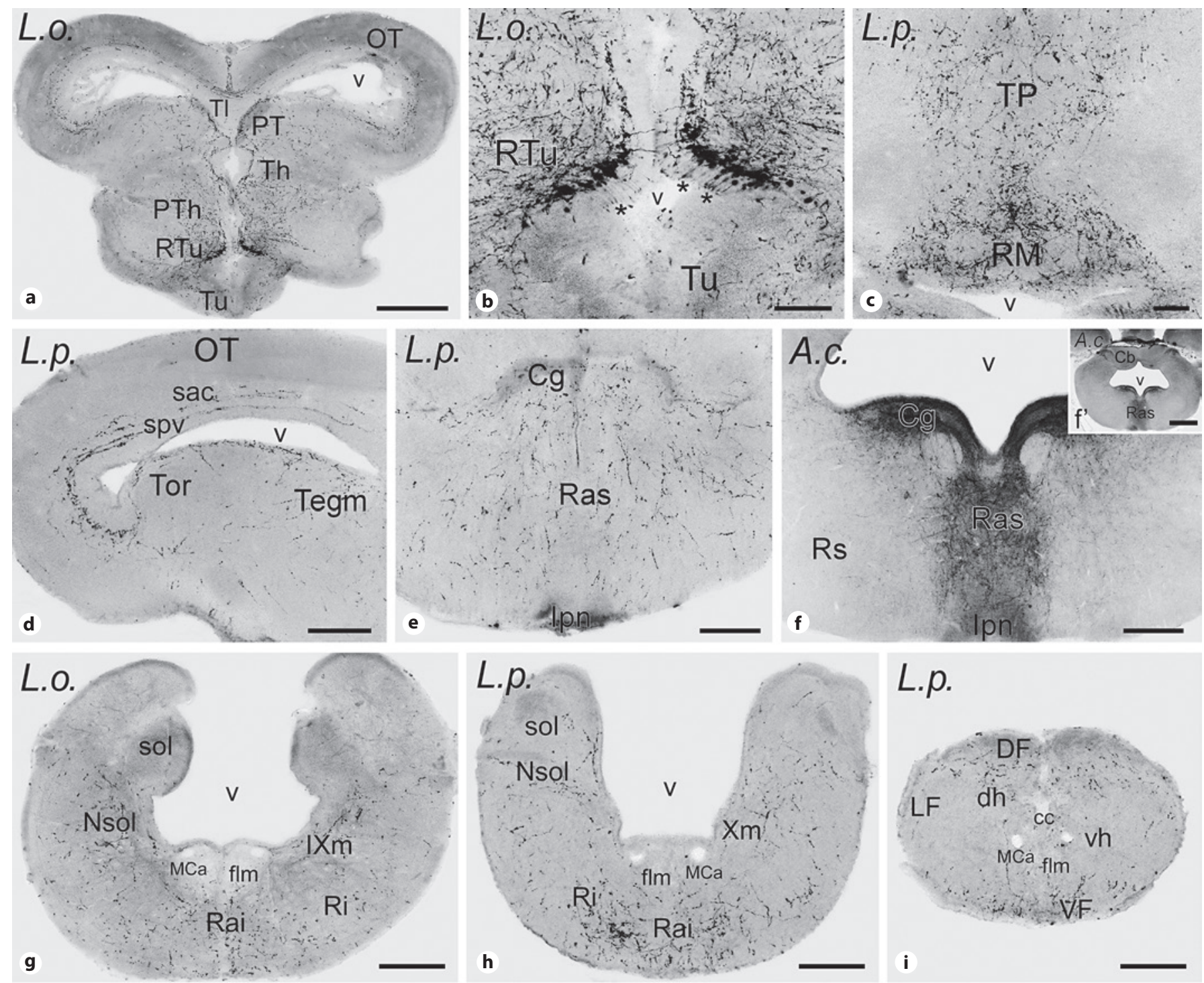

Fig. 4. Photomicrographs of transverse sections through the brain of L. platyrhincus (L.p.), L. oculatus (L.o.), and A. calva (A.c.; indicated in the upper left corner of each photomicrograph) illustrating OX-ir cells and fibers in hypothalamic, diencephalic and mesencephalic levels (a), retrotuberal hypothalamic area (b, asterisks indicate CSF-contacting cell processes), retromamillary hypothalamic area and posterior tubercle (c), optic tectum, torus semicir-

Fig. 5. Photomicrographs of transverse double-labeled sections through the forebrain and brainstem of L. platyrhincus (L.p.), $L$. oculatus (L.o.), and A. calva (A.C.; indicated in the upper right corner of each photomicrograph) showing, in the same sections, staining for orexin (OX; red fluorescence) and $\mathrm{TH}\left(\mathbf{a}, \mathbf{a}^{\prime}, \mathbf{c}, \mathbf{c}^{\prime}, \mathbf{e}\right.$, $\mathbf{h}-\mathbf{k}, \mathbf{n}, \mathbf{0}), 5-\mathrm{HT}\left(\mathbf{b}, \mathbf{f}, \mathbf{g}, \mathbf{g}^{\prime}, \mathbf{I}, \mathbf{I}^{\prime}, \mathbf{m}\right)$, or NPY (d, d') (green fluorescence), as indicated in the left corner of each photomicrograph. The relationship between the distinct immunoreactive elements in the brain is illustrated for the preoptic area (a), subpallial areas (b), suprachiasmatic nucleus $\left(\mathbf{c}, \mathbf{c}^{\prime}\right)$, retrotuberal hypothalamic area (d, arrowheads point to orexinergic cells separated from NPY-ir cells, cularis, and mesencephalic tegmentum (d), central rhombencephalic gray and superior raphe nucleus $(\mathbf{e}, \mathbf{f})$, inferior raphe, inferior reticular and solitary tract nuclei $(\mathbf{g}, \mathbf{h})$, and spinal cord (i). Photographs a-e, $\mathbf{g - i}$ correspond to levels $\mathbf{h}, \mathbf{j}, \mathbf{n}, \mathbf{r}, \mathbf{s}, \mathbf{u}, \mathbf{f}$ of Figure 1, whereas photograph $\mathbf{f}$ corresponds to level $\mathbf{n}$ of Figure 2. For abbreviations, see list. Scale bar, $500 \mu \mathrm{m}\left(\mathbf{a}, \mathbf{f}^{\prime}\right) ; 200 \mu \mathrm{m}(\mathbf{d}-\mathbf{i})$; $100 \mu \mathrm{m}(\mathbf{b}, \mathbf{c})$.

d'), prethalamic TH-ir cells in relation to the retrotuberal orexinergic cells (e, asterisks in $\mathbf{e}$ indicate CSF-contacting cell processes, $\mathbf{h}, \mathbf{I}$, ), serotonergic nucleus of the paraventricular organ in relation to the retrotuberal orexinergic cells $\left(\mathbf{f}, \mathbf{g}, \mathbf{g}^{\prime}\right)$, and OX-ir fibers in the region of the posterior tubercle $(\mathbf{j})$, retromamillary hypothalamic area $(\mathbf{k})$, superior raphe nucleus $\left(\mathbf{I}, \mathbf{I}^{\prime}\right)$, inferior raphe nucleus $(\mathbf{m})$, locus coeruleus $(\mathbf{n})$, and the solitary tract nucleus (o). Photographs $\mathbf{a}-\mathbf{d}, \mathbf{g}-\mathbf{j}$, o correspond to levels $\mathbf{c}, \mathbf{d}, \mathbf{f}, \mathbf{h}-\mathbf{j}, \mathbf{n}, \mathbf{r}, \mathbf{s}$ of Figure 1, whereas photographs $\mathbf{e}, \mathbf{f}$ correspond to levels $\mathbf{h}, \mathbf{n}$ of Figure 2. For abbreviations, see list. Scale bar, $500 \mu \mathrm{m}\left(\mathbf{a}^{\prime}, \mathbf{d}^{\prime}, \mathbf{I}^{\prime}\right), 200 \mu \mathrm{m}$ (b, $\left.\mathbf{c}^{\prime}, \mathbf{e}, \mathbf{g}^{\prime}, \mathbf{h}, \mathbf{j}, \mathbf{k}, \mathbf{m}\right), 100 \mu \mathrm{m}(\mathbf{a}, \mathbf{c}, \mathbf{d}, \mathbf{f}, \mathbf{g}, \mathbf{i}, \mathbf{I}, \mathbf{n}, \mathbf{o})$.

(For figure see next page.) 


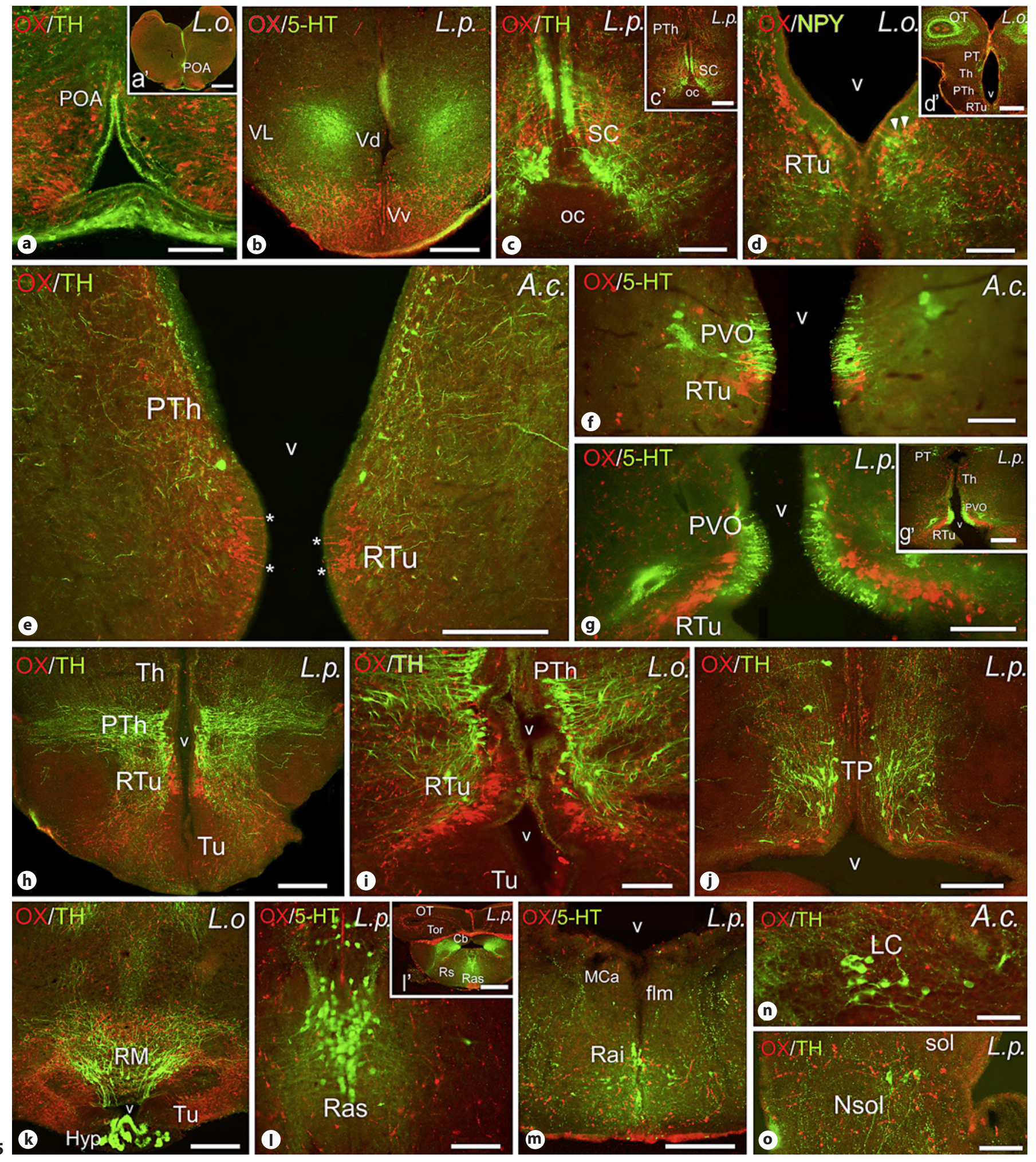


Table 1. Comparative localization and relative abundance of OX-immunoreactive cells and fibers in CNS of the holostean fishes studied

\begin{tabular}{|c|c|c|}
\hline L. platyrhincus & L. oculatus & Amia calva \\
\hline C & $\mathrm{C}$ & $\mathrm{C}$ \\
\hline
\end{tabular}

\section{Forebrain}

Telencephalon

Olfactory bulb

Pallial areas

Subpallial area $\mathrm{Vd}$

Subpallial area Vv

Subpallial area VL

Subpallial areas Vs, Vp

Preoptic area

$\begin{array}{llllll}- & + & - & + & - & + \\ - & + & - & + & - & + \\ - & + & - & + & - & + \\ - & +++ & - & +++ & - & ++ \\ - & ++ & - & ++ & - & + \\ - & + & - & + & - & + \\ ++ & +++ & + & ++ & +++ & ++\end{array}$

Hypothalamus

Paraventricular region

Subparaventricular region

Tuberal region

Retrotuberal region

Mamillary and retromamillary regions

Hypophysis

\begin{tabular}{llllll}
- & ++ & - & ++ & - & ++ \\
- & +++ & - & +++ & - & ++ \\
++ & +++ & + & +++ & ++ & ++ \\
+++ & +++ & +++ & +++ & +++ & ++ \\
- & +++ & - & +++ & - & ++ \\
- & - & - & - & - & - \\
\hline
\end{tabular}

Diencephalon

Prethalamus

Posterior tubercle

Habenula

Thalamus

Pretectum

$\begin{array}{ll}- & ++ \\ - & +++ \\ - & + \\ - & ++ \\ - & ++\end{array}$

$\begin{array}{llll}- & ++ & - & ++ \\ - & +++ & - & ++ \\ - & + & - & + \\ - & ++ & - & ++ \\ - & ++ & - & ++\end{array}$

Midbrain

Optic tectum

Torus semicircularis

Torus longitudinalis

Torus lateralis

Mesencephalic tegmentum

$\begin{array}{llllll}- & ++ & - & ++ & - & ++ \\ - & ++ & - & ++ & - & ++ \\ - & - & - & - & - & - \\ - & + & - & + & - & + \\ - & ++ & - & ++ & - & ++\end{array}$

Hindbrain

Central gray

Interpeduncular nucleus

Cerebellum

Laterodorsal tegmental nucleus

Locus coeruleus

Octavolateral area

Reticular formation

Superior raphe nucleus

Median raphe nucleus

Inferior raphe nucleus

Nucleus of the solitary tract

\begin{tabular}{llllll}
- & ++ & - & ++ & - & +++ \\
- & ++ & - & ++ & - & ++ \\
- & - & - & - & - & - \\
- & + & - & + & - & + \\
- & - & - & - & - & + \\
- & + & - & + & - & + \\
- & ++ & - & ++ & - & ++ \\
- & ++ & - & ++ & - & ++ \\
- & + & - & + & - & + \\
- & ++ & - & ++ & - & + \\
- & ++ & - & ++ & - & + \\
- & ++ & - & ++ & - & ++ \\
\hline
\end{tabular}

C, immunoreactive cell bodies; F, immunoreactive fibers; +, low density; ++, moderate density; +++, high density; -, no immunoreactive cell bodies or fibers. 


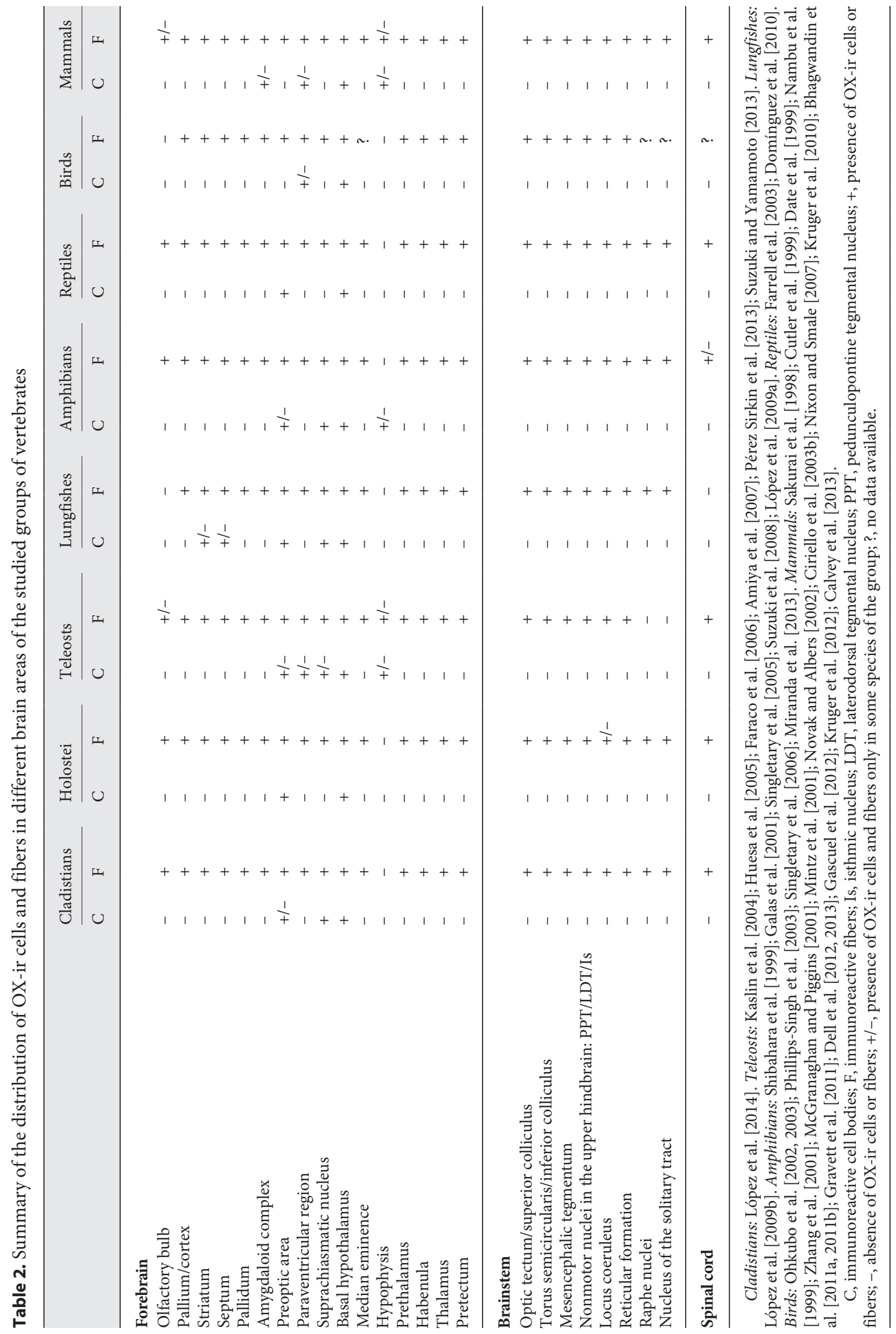


areas of the forebrain and midbrain, with the exception of the rostral rhombencephalon of $A$. calva that showed a very intense innervation in the central gray, interpeduncular neuropil, and the superior raphe nucleus (Fig. $2 \mathrm{~m}$, $\mathrm{n}, 4 \mathrm{f}, \mathrm{f})$. This innervation was low only in the 2 Lepisosteus spp. (Fig. 1m, n, 4e), although the double-labeling experiments also demonstrated OX-ir innervation of the 5 -HT cells of the raphe, primarily at the rostral and caudal poles of the column (superior raphe nucleus: Fig. 1n, o, 5l, l'; inferior raphe nucleus: Fig. 1r, s, 2s, t, 5m). In contrast, no OX-ir fibers were observed in the cerebellum, and only scattered fibers were detected in the octavolateral area and the laterodorsal tegmental nucleus in all 3 species (Fig. $1 \mathrm{~m}-\mathrm{q}, 2 \mathrm{n}-\mathrm{q}$ ), and in the region of the locus coeruleus only in A. calva (Fig. 5n).

Along the rhombencephalon, the 3 species showed OX-ir varicose fibers in the reticular formation, and in descending tracts coursing at the ventral aspect of the rhombencephalon and reaching the spinal cord (Fig. 1m$\mathrm{t}, 2 \mathrm{n}-\mathrm{t}, 4 \mathrm{~g}, \mathrm{~h}$ ). In the dorsal alar plate of the caudal rhombencephalon, some scarce orexinergic fibers were seen in the region of the nucleus of the solitary tract (Fig. 1r, s, $2 \mathrm{r}-\mathrm{t}, 4 \mathrm{~g}, \mathrm{~h}$ ), where $\mathrm{TH}$-positive cells were also observed by double-immunolabeling techniques (Fig. 5o). Occasionally, some terminal-like structures were detected among the large cell bodies of the motor nuclei of the trigeminal, facial, glossopharyngeal, and vagal nerves, which innervate the jaw musculature and muscles of the brachial arches (Fig. 1o-t, 2o-t, 4g, h).

Finally, a moderate number of OX-ir fibers reached the spinal cord, and were primarily located in the laterodorsal and ventral funiculi with only a few in the dorsal funiculus (Fig. $1 \mathrm{u}, 2 \mathrm{u}, 4 \mathrm{i}$ ). In addition, some varicose fibers and terminal-like structures were observed among the cell bodies of the dorsal horn and, more sparsely, in the intermediate and ventral spinal gray (Fig. 4i).

\section{Discussion}

The main aim of this study was to report for the first time the localization of orexin-like immunoreactivity in the brain of 3 representative species of the 2 orders of holostean fishes, Lepisosteiformes and Amiiformes. These results follow previous studies conducted by our group in cladistian fishes, lungfishes, amphibians, and reptiles [López et al., 2009a, 2009b, 2014, 2016; Domínguez et al., 2010]. The specificity of the antibodies was confirmed with control series, suggesting that the substances recognized are only orexins, although the presence of orexins

Orexins in the Brain of Holosteans in holostean fishes remains unknown. The evolution of the structure of orexins through vertebrates shows some variations in the sequence of amino acids, particularly in teleosts [Kaslin et al., 2004; Tam et al., 2011; Wong et al., 2011], but the C-terminal sequence is highly conserved in all species of vertebrates studied [Sakurai et al., 1998; Shibahara et al., 1999; Kaslin et al., 2004; Panula, 2010; Wong et al., 2011]. In addition, it has been demonstrated that the synthetic human OXA has physiological activity in teleosts [Volkoff et al., 1999, 2003; Volkoff and Peter, 2001; Nakamachi et al., 2006; Yokogawa et al., 2007], which indicates that, despite the changes in the structure of orexins in vertebrates, there is still a high similarity between orexins in teleosts and humans. The anti-OXA and anti-OXB antisera used in this study were raised against a peptide mapping at the $\mathrm{C}$-terminus of human OXA or OXA, whose invariability, together with the fact that orexins do not have structural homology with other biologically active peptides [Shibahara et al., 1999], accounts for the consistency in the immunolabeling pattern obtained with both antibodies in this and previous studies [Singletary et al., 2005, 2006; López et al., 2009a, 2009b, 2014, 2016; Domínguez et al., 2010; Miranda et al., 2013].

In the following section, we will discuss the organization of the orexinergic system in holosteans, and our results will be compared with those obtained for other groups of fishes and tetrapods (Table 2).

\section{Localization of OX-ir Neurons in the Brain of \\ Vertebrates}

The pallial and subpallial areas of holosteans lack OXir cells, representing a general feature observed in all vertebrates, with the exception of the lungfish, Neoceratodus forsteri, that contains OX-ir cells in the caudal lateral septum and in the ventral striatum [López et al., 2009b], and the rat that shows OXB-ir cells in the lateral division of the central amygdala and the rostrolateral part of the bed nucleus of stria terminalis [Ciriello et al., 2003b].

The only population of OX-ir neurons in the telencephalon of holostean fishes is located in the POA. The presence of preoptic orexinergic cells seems to be a primitive and general feature shared by most anamniotes and reptiles, with exceptions in some species of cladistians [López et al., 2014], teleosts [Amiya et al., 2007] and amphibians [López et al., 2009a]. This cell population is probably related to neurosecretion and, particularly in reptiles, this system might act as a regulator of sexual behavior [Neary and Northcutt, 1983; Kaslin et al., 2004; Crews, 2005]. In contrast, no OX-ir cells have been observed in the POA of birds and mammals (Table 2). 
The whole alar hypothalamus of holosteans studied is devoid of OX-ir cells. The absence of orexinergic cells in the paraventricular hypothalamic area is generally to be observed in all vertebrates with some specific exceptions reported in the teleost zebrafish [Kaslin et al., 2004], birds [Singletary et al., 2006; Miranda et al., 2013], and mammals [Nixon and Smale, 2007]. In contrast, the presence of orexinergic cells in the suprachiasmatic nucleus (within the subparaventricular hypothalamic area) is a primitive and generally conserved feature among anamniotes, with the exception of some teleosts [Huesa et al., 2005; Amiya et al., 2007] and holosteans (see Results). In contrast, no OX-ir cells have been reported in the suprachiasmatic nucleus of amniotes (Table 2).

The basal hypothalamus of holostean fishes houses 2 populations of orexinergic cells, situated in the $\mathrm{Tu}$ and $\mathrm{RTu}$, with the latter being the most numerous and conspicuous OX-ir cell group in the brain. The presence of orexinergic cells in the basal hypothalamus is a primitive feature highly conserved in all vertebrates, although the number and precise localization of orexin cells vary specifically depending on the vertebrate group analyzed. Thus, the number of tuberal OX-ir cells is high and the cells are widely distributed in cladistian fishes [López et al., 2014]. In teleosts, however, OX-ir cells show restricted localizations of the basal hypothalamus, i.e., the anterior hypothalamus and lateral to the posterior tuberal nucleus of zebrafish [Kaslin et al., 2004; Faraco et al., 2006], the nucleus lateralis tuberis of the anterolateral hypothalamus and the nucleus posterioris periventricularis of the goldfish, and the cichlid Cichlasoma dimerus [Huesa et al., 2005; Pérez Sirkin et al., 2013], exclusively in the nucleus lateralis tuberis of Pygocentrus nattereri [Suzuki and Yamamoto, 2013], and in the nucleus posterioris periventricularis of medaka [Amiya et al., 2007]. Of note, some studies reveal the increase in levels of the orexin precursor mRNA in the posterior tuberal nucleus of zebrafish and winter flounder after fasting for 7-14 days [Novak et al., 2005; Buckley et al., 2010] as well as an increase in the number of orexinergic cells in the same nucleus [Yokobori et al., 2012], which allows us to relate the posterior tuberal nucleus to food intake behavior, a function that might also be shared by the basal hypothalamic OX-ir cells of holosteans.

As in actinopterygian fishes, sarcopterygian anamniotes (lungfishes and amphibians) also possess OX-ir cells in the Tu [López et al., 2009a, 2009b]. Reptiles show many orexinergic cells in this area, primarily in the periventricular hypothalamic nucleus, and, in the lizard Gekko gecko only, in the dorsolateral hypothalamic nucleus [Domín- guez et al., 2010]. In the case of birds, several studies have described the presence of tuberal orexinergic cells within the periventricular hypothalamic nucleus and the lateral hypothalamic area [Ohkubo et al., 2002; Phillips-Singh et al., 2003; Singletary et al., 2006]. Likewise, populations of OX-ir cells are present in the basal hypothalamus of mammals. Thus, in the case of the rat, the orexinergic neurons have been observed in the perifornical nucleus, the dorsomedial hypothalamic nucleus, and the lateral and dorsal hypothalamic areas [Sakurai et al., 1998; Cutler et al., 1999; Date et al., 1999; Nixon and Smale, 2007; Bhagwandin et al., 2011a, 2011b; Kruger et al., 2012]. The perifornical nucleus and the lateral hypothalamus are the regions the most frequently identified with OX-ir cells in mammals, and they are involved in the control of feeding and energy balance [Winn et al., 1984; Stanley et al., 1996]. In addition, a population of orexinergic cells has been described in the ventrolateral hypothalamus, adjacent to the optic tract, in megachiropterans [Kruger et al., 2010; Dell et al., 2013], and exclusively in the medial hypothalamus of 2 Cetartiodactyla species, the giraffe and the harbor porpoise [Dell et al., 2012]. These hypothalamic populations might be involved in the roles given to orexins in the brain, i.e., food intake, reproduction, the sleep-wake cycle, and thermoregulation [Teske et al., 2010; Sakurai and Mieda, 2011].

\section{Distribution of OX-ir Fibers in the Brain of \\ Vertebrates}

Despite the restricted number of orexinergic cells in the brains of holostean fishes and vertebrates in general, OX-ir fibers are widespread and reach all main regions of the brain, and this is shared by all the groups of vertebrates studied.

In the olfactory bulbs, holosteans show scattered OX-ir fibers and terminal-like structures, mainly located in the internal granular layer, similar to the situation observed in the olfactory bulbs of cladistians, teleosts, amphibians, and reptiles [Kaslin et al., 2004; Amiya et al., 2007; Domínguez et al., 2010; López et al., 2009a, 2014], although this innervation is indeed absent in some species of teleosts, lungfishes, and birds (Table 2). In the case of mammals, studies on rodents failed to detect OX-ir fibers in the olfactory bulbs [Nixon and Smale, 2007], but they were demonstrated in more recent studies on the same species [Shibata et al., 2008; Gascuel et al., 2012], suggesting that this innervation is the connection between olfactory and hypothalamic functions [Gascuel et al., 2012].

The pallial regions of holosteans that receive orexinergic fibers are the Dlv and Dm-Dc subdivisions. These ar- 
eas were proposed to correspond to the medial and dorsal pallial regions, respectively, of the noneverted telencephalon of tetrapods [Yamamoto et al., 2007, 2017]. This limited distribution of OX-ir fibers in pallial/cortical regions is a general feature described in all groups of vertebrates studied (Table 2). On the contrary, the subpallium of holosteans possesses abundant innervation, especially in the Vv and VL, which would correspond to the septal-pallidal region of tetrapods, according to the pattern of labeling of some neuromarkers and transcription factors [Braford Jr, 2009; González et al., 2014].

Of note, in cladistians, not only the $\mathrm{Vv}$ but also the $\mathrm{Vd}$ shows abundant OX-ir fibers [López et al., 2014]. In the rest of the vertebrate groups, orexin innervation has been found in the striatum (equivalent to the $\mathrm{Vd}$ ), septum, pallidum, and amygdaloid complex (equivalent to the Vs and Vp) [Kaslin et al., 2004; Singletary et al., 2005; Bisetti et al., 2006; Nixon and Smale, 2007; López et al., 2009a, 2009b; Domínguez et al., 2010; Schmitt et al., 2012]. These orexinergic fibers activate the basal forebrain cholinergic system in mammals in states of food deprivation [Wu et al., 2002, 2004; Fadel and Frederick-Duus, 2008]. This could also occur in reptiles, amphibians, and lungfishes, due to the codistribution of OX-ir fibers and cholinergic cells [López et al., 2009a, 2009b; Domínguez et al., 2010], as well as in holostean fishes because orexinergic fibers that reach the Vv and VL might innervate the cholinergic cells located in these areas [Morona et al., 2013].

In the alar hypothalamus of holosteans, the scarce orexinergic innervation observed in the paraventricular region and the dense innervation of the suprachiasmatic region concur with similar observations in all vertebrate groups studied [McGranaghan and Piggins, 2001; Mintz et al., 2001; Kaslin et al., 2004; Singletary et al., 2006; López et al., 2009a, 2009b, 2014; Domínguez et al., 2010]. In the case of the suprachiasmatic nucleus, this innervation can explain the tight relationship between the orexinergic system and the control of circadian rhythmicity [Klisch et al., 2009; Blasiak et al., 2017]. In the basal hypothalamus of holostean fishes, along with the OX-ir cells, abundant fibers course in the tuberal region and reach the median eminence, as has also been observed in cladistians, lungfishes, amphibians, reptiles, and mammals [Peyron et al., 1998; Date et al., 2000; López et al., 2009a, 2009b, 2014; Domínguez et al., 2010].

Previous studies have already dealt with the involvement of the orexinergic system in the control of the adenohypophysis [Kukkonen et al., 2002; Ferguson and Samson, 2003], regulating the liberation of ACTH, GH, gonadotropins, $\mathrm{LH}$, and prolactin in rats $[\mathrm{Pu}$ et al., 1998;
Kuru et al., 2000; Blanco et al., 2001; Kohsaka et al., 2001; Porkka-Heiskanen et al., 2004; Seoane et al., 2004; Kiyokawa et al., 2011; Cataldi et al, 2014]. Of note, orexins inhibit the gonadotropin-releasing hormone system that produces reproductive behavior in goldfish [Hoskins et al., 2008]. These data suggest a role of orexins in the interaction between energy homeostasis and reproduction in teleosts and mammals, and this might extend to the rest of the vertebrates.

As in holostean fishes, the hypophysis of almost all vertebrates studied lacks orexinergic cells or fibers (Table 2), but there are some reports of the observation of hypophyseal OX-ir cells in some species of teleosts [Amiya et al., 2007; Suzuki et al., 2009; Pérez Sirkin et al., 2013; Suzuki and Yamamoto, 2013], in anurans [Yamamoto et al., 2004; Suzuki et al., 2007], and in humans [Blanco et al., 2003]. These differences most likely are related to technical variations in the use of different antibodies or the sensitivity of the immunostaining.

In the diencephalon of holosteans, the 3 prosomeres are moderately innervated with orexin varicose fibers, and this innervation is more conspicuous in the thalamic region. All vertebrates studied possess orexin innervation in the thalamus (Table 2), suggesting that this is a highly conserved feature. In mammals, thalamic innervation arises in the orexinergic cells located in the lateral hypothalamus, and is probably involved in feeding behavior [Lee and Lee, 2016] and in arousal states via projections to the limbic forebrain areas [Kirouac et al., 2005; Nixon and Smale, 2007; Pasumarthi and Fadel, 2008]. This may also occur in amphibians and reptiles, as the thalamic nuclei which are innervated by orexinergic fibers are connected to the nucleus accumbens, septum, and amygdala, all 3 basal limbic forebrain areas [Marín et al., 1997; Ten Donkelaar, 1998].

The mesencephalon of holosteans possesses a notable amount of OX-ir fibers and terminal-like structures in the optic tectum and torus semicircularis, observed in every group of vertebrates studied (Table 2), suggesting a role of orexins in visual and auditory processing and the integration of other sensory and motor information. The distribution of OX-ir fibers in the mesencephalic tegmentum also shows great similarities across all vertebrate groups.

The rhombencephalon shows moderate orexinergic innervation in the rostral cholinergic groups, the reticular formation, and the nucleus of the solitary tract; not only in holostean fishes but also in most vertebrates (Table 2). Specifically, the OX-ir fibers in the cholinergic nucleus of alar rhombomere 1 of holosteans, identified as the equiv- 
alent of the pedunculopontine and laterodorsal tegmental nuclei of amniotes [Morona et al., 2013], could innervate the cells of these nuclei, as has been described in other vertebrates [Peyron et al., 1998; Cutler et al., 1999; Nambu et al., 1999; McGranaghan and Piggins, 2001; Mintz et al., 2001; Kaslin et al., 2004; López et al., 2009a, 2009b; Domínguez et al., 2010; Kruger et al., 2010; Dell et al., 2013]. This innervation might account for the orexin regulation of the activity of these nuclei, thus controlling states of arousal and sleep-wakefulness [Kim et al., 2009; Hong et al., 2011; Kohlmeier et al., 2013]. Moreover, the OX-ir innervation observed in the nucleus of the solitary tract is very likely the basis of the orexinergic regulation of autonomic-cardiovascular responses, such as heart rate and arterial pressure [Smith et al., 2002; Ciriello et al., 2003a, 2013; de Oliveira et al., 2003; Shih and Chuang, 2007; Shahid et al., 2012].

In the rhombencephalon of holosteans, the motor nuclei of the trigeminal, facial, glossopharyngeal and vagal nerves showed scarce OX-ir innervation, which has been observed in the same nuclei of cladistians [López et al., 2014]. Of note, orexinergic innervation has been reported in trigeminal and hypoglossal motoneurons of mammals [Fung et al., 2001; McGregor et al., 2005]. In addition, the octavolateral area of holosteans shows a few orexinergic fibers, which is a feature that has been observed in some vertebrates, like cladistians [López et al., 2014] and lungfishes [López et al., 2009a], and in the medial vestibular nucleus of the hamster [Horowitz et al., 2005].

Finally, the spinal cord of holostean fishes is moderately innervated by orexin fibers located mainly in the laterodorsal and ventral funiculi, with terminal-like structures in the dorsal, intermediate, and ventral spinal gray, as has been described in cladistian fishes, teleosts, some amphibians, reptiles, and mammals (Table 2). It has been reported that in rodents, functionally, orexins modulate pain sensation and regulate the autonomous nervous system by the innervation in the marginal zone, lamina 10 , and the intermediolateral column of the spinal cord [van den Pol, 1999; Date et al., 2000; LlewellynSmith et al., 2003], with antinociceptive actions demonstrated in the spinal and supraspinal levels [Mobarakeh et al., 2005; Chiou et al., 2010; Azhdari Zarmehri et al., 2011].

\section{Possible Relationships between the Orexinergic, NPY, and Monoaminergic Systems}

The simultaneous observation in the same sections of OX-ir elements and NPY-ir, TH-ir, or 5-HT-ir cells and fibers was useful to accurately characterize their localiza- tion in the brain. In addition, the double-labeling experiments highlight possible interactions between these systems in the brains of holosteans. Although it was not the aim of our study to analyze and demonstrate connections between the labeled structures (no electron or confocal microscopy was used), we will comment on the possible places of interactions and compare them with previous data from other vertebrate groups.

NPY is a highly conserved neuropeptide with orexigenic properties, whose expression in the hypothalamus of teleosts is induced by orexins [Nisembaum et al., 2014]. One of the main functions of this neuropeptide in teleosts is the increase of food intake, in synergistic action with orexins [Volkoff, 2006, 2012; Pérez Sirkin et al., 2013]. Our results regarding the possible interaction of NPY and orexins in holostean fishes show the lack of colocalization of both peptides in the same cells, albeit that intermingled populations of NPY-ir and OX-ir cells are located in the RTu. However, the NPY-ir neurons are possibly innervated by OX-ir fibers because of the close relationship of these 2 elements observed in the double-labeled sections. Reciprocally, NPY-ir fibers may innervate OX-ir cells. These interactions are likely present in the POA, RTu, and Tu. A similar relationship between orexins and NPY has also been described in the Tu of cladistians [López et al., 2014] and in the nucleus posterioris periventricularis of the goldfish, with observations of possible mutual innervation [Kojima et al., 2009; Shahjahan et al., 2014]. Noteworthy experimental data indicate that the orexigenic actions of OXA and NPY are mediated by mutual signaling pathways in goldfish [Volkoff and Peter, 2001; Kojima et al., 2009; Matsuda, 2009]. In rodents, distinct and nonoverlapping groups of NPY-ir and OX-ir cells were observed in the lateral hypothalamus, and NPY-ir nerve terminals have been observed surrounding and in close relationship to perikarya and processes of OX-ir cells [Broberger et al., 1998; Marston et al., 2011]. Furthermore, the interactions of both systems were strengthened with the demonstration of the effective inhibition by NPY receptor antagonists of the feeding behavior induced by OXA [Dube et al., 2000; Yamanaka et al., 2000].

No actual colocalization in the same neurons of orexins with $\mathrm{TH}$ and 5-HT was observed at any location in the brain of holosteans, although several TH-ir and 5-HT-ir cell populations are innervated by orexinergic fibers. Conspicuous OX-ir fibers and terminal-like structures are distributed close to and around the TH-ir neurons of the suprachiasmatic nucleus and the posterior tubercle, the latter being the origin of the ascending dopaminergic system to the subpallium in teleosts, an equivalent struc- 
ture to the dopaminergic ventral tegmental area/substantia nigra of mammals [Rink and Wullimann, 2001, 2002, 2004]. Several studies have shown that intraperitoneal injections of orexins increase the mRNA expression of TH in the brain of the cavefish [Penney and Volkoff, 2014], and intracerebroventricular administration of OXA in the goldfish increases locomotor activity [Nakamachi et al., 2006; Matsuda et al., 2011]. Furthermore, studies on rodents have shown that OXA stimulates hyperlocomotion, and that the effect is inhibited by dopamine antagonists [Nakamura et al., 2000]. This orexin-induced locomotor activity exerted by the mesencephalic dopaminergic cells of mammals has a probable counterpart in the $\mathrm{TH}$-ir cells (dopaminergic; unpublished data) of the posterior tubercle of holosteans and other actinopterygian fishes.

Abundant orexinergic fibers and terminals could also be observed interspersed with the $\mathrm{TH}$-ir cells of the POA, the RM and, to a lesser extent, the nucleus of the solitary tract, as well as with the serotonergic cells of the raphe column. These results are largely similar to those obtained in goldfish [Huesa et al., 2005] and cladistian fishes, with the exception of the actual colocalization of orexin and TH in cells of the POA of Polypterus [López et al., 2014]. Moreover, orexin interactions with the cholinergic and histaminergic systems have been reported in zebrafish [Kaslin et al., 2004; Chiu and Prober, 2013]. These interactions in actinopterygian fishes probably represent a primitive and incipient feature, which would have evolved more conspicuously in the brains of sarcopterygian vertebrates (lungfishes and tetrapods) [Peyron et al., 1998; Nambu et al., 1999; Fadel and Deutch, 2002; Baldo et al., 2003; Ferguson and Samson, 2003; Bubser et al.,
2005; Lee et al., 2005; Singletary et al., 2006; Yoshida et al., 2006; Balcita-Pedicino and Sesack, 2007; Nixon and Smale, 2007; Vittoz et al., 2008; López et al., 2009a, 2009b; Domínguez et al., 2010; Kruger et al., 2010; Gravett et al., 2011; Dell et al., 2013].

The neuroanatomical distribution of the orexinergic system found in the 3 species of holosteans showed a general pattern largely comparable to those of teleosts, their sister group. In some aspects, the highly conserved traits of this system are observed throughout vertebrates, such as the presence of OX-ir cells in the basal hypothalamus, suggesting a preservation of the physiological functions of orexins. From studies on teleosts, major functional roles of orexins would be related to food intake, regulation of the sleep/wakefulness cycle, reproduction, and locomotor activity, i.e., functions that most likely would be exerted in close relation with other neurotransmission systems, such as the catecholaminergic, the serotonergic, and the NPY systems, among others.

\section{Acknowledgements}

This work was supported by a Spanish MICINN grant, grant/ award No. BFU2015-66041P (with European FEDER support).

\section{Disclosure Statement}

The authors declare that they have no conflicts of interest. No financial conflict of interest was identified, and the terms of the funding arrangement were reviewed and approved by the Complutense University of Madrid in accordance with its policy on objectivity in research.

\section{References}

Adams JC (1981): Heavy metal intensification of DAB-based HRP reaction product. J Histochem Cytochem 29:775.

Alvarez CE, Sutcliffe JG (2002): Hypocretin is an early member of the incretin gene family. Neurosci Lett 324:169-172.

Amiya N, Amano M, Oka Y, Iigo M, Takahashi A, Yamamori K (2007): Immunohistochemical localization of the orexin/hypocretin-like immunoreactive peptides and melanin-concentrating hormone in the brain and pituitary of medaka. Neurosci Lett 427:16-21.

Aroca P, Puelles L (2005): Postulated boundaries and differential fate in the developing rostral hindbrain. Brain Res Brain Res Rev 49:179190.
Azhdari Zarmehri H, Semnanian S, Fathollahi Y, Erami E, Khakpay R, Azizi H, Rohampour K (2011): Intra-periaqueductal gray matter microinjection of orexin-A decreases formalininduced nociceptive behaviors in adult male rats. J Pain 12:280-287.

Baker BI, Bird DJ (2002): Neuronal organization of the melanin-concentrating hormone system in primitive actinopterygians: evolutionary changes leading to teleosts. J Comp Neurol 442:99-114

Balcita-Pedicino JJ, Sesack SR (2007): Orexin axons in the rat ventral tegmental area synapse infrequently onto dopamine and gammaaminobutyric acid neurons. J Comp Neurol 503:668-684.
Baldo BA, Daniel RA, Berridge CW, Kelley AE (2003): Overlapping distributions of orexin/ hypocretin- and dopamine-beta-hydroxylase immunoreactive fibers in rat brain regions mediating arousal, motivation, and stress. J Comp Neurol 464:220-237.

Bhagwandin A, Fuxe K, Bennett NC, Manger PR (2011a): Distribution of orexinergic neurons and their terminal networks in the brains of two species of African mole rats. J Chem Neuroanat 41:32-42.

Bhagwandin A, Gravett N, Hemingway J, Oosthuizen MK, Bennett NC, Siegel JM, Manger PR (2011b): Orexinergic neuron numbers in three species of African mole rats with rhythmic and arrhythmic chronotypes. Neuroscience 199:153-165. 
Bisetti A, Cvetkovic V, Serafin M, Bayer L, Machard D, Jones BE, Mühlethaler M (2006): Excitatory action of hypocretin/orexin on neurons of the central medial amygdala. Neuroscience 142:999-1004.

Blanco M, Gallego R, Garcia-Caballero T, Dieguez C, Beiras A (2003): Cellular localization of orexins in human anterior pituitary. Histochem Cell Biol 120:259-264.

Blanco M, López M, García-Caballero T, Gallego R, Vázquez-Boquete A (2001): Cellular localization of orexin receptors in human pituitary. J Clin Endocrinol Metab 86:1616-1619.

Blasiak A, Gundlach AL, Hess G, Lewandowski MH (2017): Interactions of circadian rhythmicity, stress and orexigenic neuropeptide systems: Implications for food intake control. Front Neurosci 11:127.

Braford MR Jr (2009): Stalking the everted telencephalon: comparisons of forebrain organization in basal ray-finned fishes and teleosts. Brain Behav Evol 74:56-76.

Broberger C, de Lecea L, Sutcliffe JG, Hokfelt T (1998): Hypocretin/orexin- and melaninconcentrating hormone-expressing cells form distinct populations in the rodent lateral hypothalamus: relationship to the neuropeptide $\mathrm{Y}$ and agouti gene-related protein systems. J Comp Neurol 402:460-474.

Broughton RE, Betancur-R R, Li C, Arratia G, Ortí G (2013): Multi-locus phylogenetic analysis reveals the pattern and tempo of bony fish evolution. PLoS Curr, DOI: 10.1371/currents. tol.2ca8041495ffafd0c92756e75247483e.

Bubser M, Fadel JR, Jackson LL, Meador-Woodruff JH, Jing D, Deutch AY (2005): Dopaminergic regulation of orexin neurons. Eur J Neurosci 21:2993-3001.

Buckley C, MacDonald EE, Tuiak SM, Volkoff H (2010): Molecular cloning and characterization of two putative appetite regulators in winter flounder (Pleuronectes americanus): preprothyrotropin-releasing hormone (TRH) and preproorexin (OX). Peptides 31:17371747.

Butler AB, Northcutt RG (1992): Retinal projections in the bowfin, Amia calva: cytoarchitectonic and experimental analysis. Brain Behav Evol 39:169-194.

Calvey T, Patzke N, Kaswera C, Gilissen E, Bennett NC, Manger PR (2013): Nuclear organization of some immunohistochemically identifiable neural systems in three Afrotherian species - Potomogale velox, Amblysomus hottentotus and Petrodomus tetradactylus. J Chem Neuroanat 50-51:48-65.

Cataldi NI, Lux Lantos VA, Libertun C (2014): Orexin $A$ and $B$ in vitro modify orexins receptors expression and gonadotropins secretion of anterior pituitary cells of proestrous rats. Regul Pept 188:25-30.

Chiba A (2005): Neuropeptide Y-immunoreactive (NPY-ir) structures in the brain of the gar Lepisosteus oculatus (Lepisosteiformes, Osteichthyes) with special regard to their anatomical relations to gonadotropin-releasing hormone $(\mathrm{GnRH})$-ir structures in the hypo- thalamus and the terminal nerve. Gen Comp Endocrinol 142:336-346.

Chiba A, Oka S (1999): Serotonin-immunoreactive structures in the central nervous system of the garfish Lepisosteus productus (Semionotiformes, Osteichthyes). Neurosci Lett 261: 73-76.

Chiou LC, Lee HJ, Ho YC, Chen SP, Liao YY, Ma $\mathrm{CH}$, et al (2010): Orexins/hypocretins: pain regulation and cellular actions. Curr Pharm Des 16:3089-3100.

Chiu CN, Prober CA (2013): Regulation of zebrafish sleep and arousal states: current and prospective approaches. Front Neural Circ 7: 58.

Ciriello J, Caverson MM, McMurray JC, Bruckschwaiger EB (2013): Co-localization of hypocretin-1 and leucine-enkephalin in hypothalamic neurons projecting to the nucleus of the solitary tract and their effect on arterial pressure. Neuroscience 250:599-613.

Ciriello J, McMurray JC, Babic T, de Oliveira CV (2003a): Collateral axonal projections from hypothalamic hypocretin neurons to cardiovascular sites in nucleus ambiguus and nucleus tractus solitarius. Brain Res 991:133-141.

Ciriello J, Rosas-Arellano MP, Solano-Flores LP, de Oliveira CV (2003b): Identification of neurons containing orexin-B (hypocretin-2) immunoreactivity in limbic structures. Brain Res 967:123-132.

Collin SP, Northcutt RG (1995): The visual system of the Florida garfish, Lepisosteus platyrhincus (Ginglymodi). IV. Bilateral projections and the binocular visual field. Brain Behav Evol 45:34-53.

Crews D (2005): Evolution of neuroendocrine mechanisms that regulate sexual behavior. Trends Endocrinol Metab 16:354-361.

Cutler DJ, Morris R, Sheridhar V, Wattam TA Holmes S, Patel S, et al (1999): Differential distribution of orexin-A and orexin-B immunoreactivity in the rat brain and spinal cord. Peptides 20:1455-1470.

Date Y, Mondal MS, Matsukura S, Nakazato M (2000): Distribution of orexin-A and orexin$\mathrm{B}$ (hypocretins) in the rat spinal cord. Neurosci Lett 288:87-90.

Date Y, Ueta Y, Yamashita H, Yamaguchi H, Matsukura S, Kangawa K, et al (1999): Orexins, orexinergic hypothalamic peptides, interact with autonomic, neuroendocrine and neuroregulatory systems. Proc Natl Acad Sci USA 96:748-753.

de Lecea L, Kilduff TS, Peyron C, Gao X, Foye PE, Danielson PE, et al (1998): The hypocretins: hypothalamus-specific peptides with neuroexcitatory activity. Proc Natl Acad Sci USA 95:322-327.

Dell LA, Kruger JL, Pettigrew JD, Manger PR (2013): Cellular location and major terminal networks of the orexinergic system in the brain of two megachiropterans. J Chem Neuroanat 53:64-71.

Dell LA, Patzke N, Bhagwandin A, Bux F, Fuxe K, Barber G, Siegel JM, Manger PR (2012): Or- ganization and number of orexinergic neurons in the hypothalamus of two species of Cetartiodactyla: a comparison of giraffe (Giraffa camelopardalis) and harbour porpoise (Phocoena phocoena). J Chem Neuroanat 44: 98-109.

de Oliveira CV, Rosas-Arellano MP, SolanoFlores LP, Ciriello J (2003): Cardiovascular effects of hypocretin- 1 in nucleus of the solitary tract. Am J Physiol Heart Circ Physiol 284:H1369-H1377.

Domínguez L, Morona R, Joven A, González A, López JM (2010): Immunohistochemical localization of orexins (hypocretins) in the brain of reptiles and its relation to monoaminergic systems. J Chem Neuroanat 39: 20-34.

Dube MG, Horvath TL Kalra PS, Kalra SP (2000): Evidence of NPY Y 5 receptor involvement in food intake elicited by orexin $\mathrm{A}$ in sated rats. Peptides 21:1557-1560.

Fadel J, Deutch AY (2002): Anatomical substrates of orexin-dopamine interactions: lateral hypothalamic projections to the ventral tegmental area. Neuroscience 111:379-387.

Fadel J, Frederick-Duus D (2008): Orexin/hypocretin modulation of the basal forebrain cholinergic system: insights from in vivo microdialysis studies. Pharmacol Biochem Behav 90:156-162.

Faraco JH, Appelbaum L, Marin W, Gaus SE, Mourrain P, Mignot E (2006): Regulation of hypocretin (orexin) expression in embryonic zebrafish. J Biol Chem 281:29753-29761.

Farrell WJ, Delville Y, Wilczynski W (2003): Immunocytochemical localization of orexin in the brain of the green anole lizard (Anolis carolinensis). Soc Neur Abstract 33:828.4.

Ferguson AV, Samson WK (2003): The orexin/ hypocretin system: a critical regulator of neuroendocrine and autonomic function. Front Neuroendocrinol 24:141-150.

Fung SJ, Yamuy J, Sampogna S, Morales FR, Chase MH (2001): Hypocretin (orexin) input to trigeminal and hypoglossal motoneurons in the cat: a double-labeling immunohistochemical study. Brain Res 903:257-262.

Galas L, Vaudry H, Brain B, van den Pol AN, de Lecea L, Sutcliffe JG, Chartrel N (2001): Immunohistochemical localization and biochemical characterization of hypocretin/ orexin-related peptides in the central nervous system of the frog Rana ridibunda. J Comp Neurol 429:242-252.

Gascuel J, Lemoine A, Rigault C, Datiche F, Benani A, Penicaud L, Lopez-Mascaraque L (2012): Hypothalamus-olfactory system crosstalk: orexin A immunostaining in mice. Front Neuroanat 6:44.

Gilland E, Baker R (1993): Conservation of neuroepithelial and mesodermal segments in the embryonic vertebrate head. Acta Anat (Basel) 148:110-123.

González A, Morona R, Moreno N, Bandín S, López JM (2014): Identification of striatal and pallidal regions in the subpallium of anamniotes. Brain Behav Evol 83:93-103. 
Gravett N, Bhagwandin A, Fuxe K, Manger PR (2011): Distribution of orexin-A immunoreactive neurons and their terminal networks in the brain of the rock hyrax, Procavia capensis. J Chem Neuroanat 41:86-96.

Heijdra YF, Nieuwenhuys R (1994): Topological analysis of the brainstem of the bowfin, Amia calva. J Comp Neurol 339:12-26.

Hong EY, Yoon YS, Lee HS (2011): Differential distribution of melanin-concentrating hormone (MCH)- and hypocretin (Hcrt)-immunoreactive neurons projecting to the mesopontine cholinergic complex in the rat. Brain Res 1424:20-31.

Horowitz SS, Blanchard J, Morin LP (2005): Medial vestibular connections with the hypocretin (orexin) system. J Comp Neurol 487:127-146.

Hoskins LJ, Xu M, Volkoff H (2008): Interactions between gonadotropin-releasing hormone $(\mathrm{GnRH})$ and orexin in the regulation of feeding and reproduction in goldfish (Carassius auratus). Horm Behav 54:379-385.

Huesa G, van den Pol AN, Finger TE (2005): Differential distribution of hypocretin (orexin) and melanin-concentrating hormone in the goldfish brain. J Comp Neurol 488:476-491.

Irisarri I, Baurain D, Brinkmann H, Delsuc F, Sire JY, Kupfer A, et al (2017): Phylotranscriptomic consolidation of the jawed vertebrate timetree. Nat Ecol Evol 1:1370-1378.

Kaslin J, Nystedt JM, Ostergard M, Peitsaro N, Panula P (2004): The orexin/hypocretin system in zebrafish is connected to the aminergic and cholinergic systems. J Neurosci 24:26782689.

Kim J, Nakajima K, Oomura Y, Wayner MJ, Sasaki K (2009): Electrophysiological effects of orexins/hypocretins on pedunculopontine tegmental neurons in rats: an in vitro study. Peptides 30:191-209.

Kirouac GJ, Parsons MP, Li S (2005): Orexin (hypocretin) innervation of the paraventricular nucleus of the thalamus. Brain Res 1059: 179-188.

Kiyokawa M, Matsuzaki T, Iwasa T, Ogata R, Murakami M, Kinouchi R, et al (2011): Neuropeptide Y mediates orexin A-mediated suppression of pulsatile gonadotropin-releasing hormone secretion in ovariectomized rats. J Med Invest 58:11-18.

Klisch C, Inyushkin a, Mordel J, Karnas D, Pévet P, Meissl H (2009): Orexin A modulates neuronal activity of the rodent suprachiasmatic nucleus in vitro. Eur J Neurosci 30:65-75.

Kohlmeier KA, Tyler CJ, Kalogiannis M, Ishibashi M, Kristensen MP, Gumenchuk I, et al (2013): Differential actions of orexin receptors in brainstem cholinergic and monoaminergic neurons revealed by receptor knockouts: implications for orexinergic signaling in arousal and narcolepsy. Front Neurosci 7:246.

Kohsaka A, Watanobe H, Kakizaki Y, Suda T, Schioth HB (2001): A significant participation of orexin-A, a potent orexigenic peptide, in the preovulatory luteinizing hormone and prolactin surges in the rat. Brain Res 898:166170.
Kojima K, Kamijo M, Kageyama H, Uchiyama M, Shioda S, Matsuda K (2009): Neuronal relationship between orexin-A- and neuropeptide $\mathrm{Y}$-induced orexigenic actions in goldfish. Neuropeptides 43:63-71.

Kruger JL, Dell LA, Pettigrew JD, Manger PR (2010): Cellular location and major terminal networks of the orexinergic system in the brains of five microchiropteran species. J Chem Neuroanat 40:256-262.

Kruger JL, Patzke N, Fuxe K, Bennett NC, Manger PR (2012): Nuclear organization of cholinergic, putative catecholaminergic, serotonergic and orexinergic systems in the brain of the African pygmy mouse (Mus minutoides): organizational complexity is preserved in small brains. J Chem Neuroanat 44:45-56.

Kukkonen JP, Holmqvist T, Ammoun S, Akerman KE (2002): Functions of the orexinergic/ hypocretinergic system. Am J Physiol Cell Physiol 283:C1567-91.

Kuru M, Ueta Y, Serino R, Nakazato M, Yamamoto Y, Shibuya I (2000): Centrally administered orexin/hypocretin activates HPA axis in rats. Neuroreport 11:1977-1980.

Lee EY, Lee HS (2016): Dual projections of single orexin- or CART-immunoreactive, lateral hypothalamic neurons to the paraventricular thalamic nucleus and nucleus accumbens shell in the rat: light microscopic study. Brain Res, 1634:104-118.

Lee HS, Park SH, Song WC, Waterhouse BD (2005): Retrograde study of hypocretin-1 (orexin-A) projections to subdivisions of the dorsal raphe nucleus in the rat. Brain Res 1059:35-45.

Llewellyn-Smith IJ, Martin CL, Marcus JN, Yanagisawa M, Minson JB, Scammell TE (2003): Orexin-immunoreactive inputs to rat sympathetic preganglionic neurons. Neurosci Lett 351:115-119.

López JM, Domínguez L, Moreno N, Morona R, Joven A, González A (2009a): Distribution of orexin/hypocretin immunoreactivity in the brain of the lungfishes Protopterus dolloi and Neoceratodus forsteri. Brain Behav Evol 74: 302-322.

López JM, Domínguez L, Moreno N, González A (2009b): Comparative immunohistochemical analysis of the distribution of orexins (hypocretins) in the brain of amphibians. Peptides 30:873-887.

López JM, Lozano D, Morales L, González A (2017): Pattern of nitrergic neuronal system organization in the brain of two holostean fishes (Actinopterygii, Ginglymodi). Brain Behav Evol 89:117-152.

López JM, Morales L, González A (2016): Spatiotemporal development of the orexinergic (hypocretinergic) system in the central nervous system of Xenopus laevis. Brain Behav Evol 88:127-146.

López JM, Sanz-Morello B, González A (2014): Organization of the orexin/hypocretin system in the brain of two basal actinopterygian fishes, the cladistians Polypterus senegalus and Erpetoichthys calabaricus. Peptides 61:23-37.
Malz CR, Jahn H, Meyer DL (1999): Centrifugal Phe-Met-Arg-Phe- $\mathrm{NH}_{2}$-like immunoreactive innervation of the retina in a non-teleost bony fish, Lepisosteus osseous. Neurosci Lett 264: 33-36.

Marín O, González A, Smeets WJ (1997): Basal ganglia organization in amphibians: afferent connections to the striatum and the nucleus accumbens. J Comp Neurol 378:16-49.

Marston OJ, Hurst P, Evans M, Burdakov DI, Heisler LK (2011): Neuropeptide Y cells represent a distinct glucose-sending population in the lateral hypothalamus. Endocrinology 152:4046-4052.

Matsuda K (2009): Recent advances in the regulation of feeding behavior by neuropeptides in fish. Ann NY Acad Sci 1163:243-252.

Matsuda K, Asuma M, Kang KS (2012): Orexin system in teleost fish; in Litwack G (ed): Vitamins and Hormones, vol 89. Burlington, Academic Press, pp 341-361.

Matsuda K, Kang KS, Sakashita A, Yahashi S, Vaudry H (2011): Behavioral effect of neuropeptides related to feeding regulation in fish. Ann NY Acad Sci 1220:117-126.

McCormick CA (1981): Central projections of the lateral line and eighth nerves in the bowfin, Amia calva. J Comp Neurol 197:1-15.

McGranaghan PA, Piggins HD (2001): Orexin-Alike immunoreactivity in the hypothalamus and thalamus of the Syrian hamster (Mesocricetus auratus) and Siberian hamster (Phodopus sungorus), with special reference to circadian structures. Brain Res 904:234-244.

McGregor R, Damian A, Fabbiani G, Torterolo P, Pose I, Chase M, Morales FR (2005): Direct hypothalamic innervation of the trigeminal motor nucleus: a retrograde tracer study. Neuroscience 134:1073-1081.

Meek J, Nieuwenhuys R (1998): Holosteans and teleosts; in Nieuwenhuys R, Ten Donkelaar HJ, Nicholson C (eds): The Central Nervous System of Vertebrates, vol 2. Berlin, Springer, pp 759-937.

Mintz EM, van den Pol AN, Casano AA, Albers HE (2001): Distribution of hypocretin(orexin) immunoreactivity in the central nervous system of Syrian hamsters (Mesocricetus auratus). J Chem Neuroanat 21:225-238.

Miranda B, Esposito V, de Girolamo P, Sharp PJ, Wilson PW, Dunn IC (2013): Orexin in the chicken hypothalamus: immunocytochemical localization and comparison of mRNA concentrations during the day and night, and after chronic food restriction. Brain Res 1513:34-40.

Mobarakeh JI, Takahashi K, Sakurada S, Nishino S, Watanabe H, Kato M, Yanai K (2005): Enhanced antinociception by intracerebroventricularly and intrathecally-administered orexin A and B (hypocretin-1 and -2) in mice. Peptides 26:767-777.

Morona R, López JM, Northcutt RG, González A (2013): Comparative analysis of the organization of the cholinergic system in the brain of two holostean fishes, the Florida gar Lepisosteus platyrhincus and the bowfin Amia calva. Brain Behav Evol 81:109-142. 
Nakamachi T, Matsuda K, Maruyama K, Miura T, Uchiyama M, Funahashi H, et al (2006): Regulation by orexin of feeding behavior and locomotor activity in the goldfish. J Neuroendocrinol 19:290-297.

Nakamura T, Uramura K, Nambu T, Yada T, Goto K, Yanagisawa M, Sakurai T (2000): orexin-induced hyperlocomotion and stereotypy are mediated by the dopaminergic system. Brain Res 873:181-187.

Nambu T, Salurai T, Mizukami K, Hosoya Y, Yanagisawa M, Goto K (1999): Distribution of orexin neurons in the adult rat brain. Brain Res 827:243-260.

Near TJ, Eytan RI, Dornburg A, Kuhn KL, Moore JA, Davis MP, et al (2012): Resolution of rayfinned fish phylogeny and timing of diversification. Proc Natl Acad Sci USA 109:1369813703.

Neary TJ, Northcutt RG (1983): Nuclear organization of the bullfrog diencephalon. J Comp Neurol 213:262-278.

Nelson JS (ed) (2006): Fishes of the World, ed 4. Hoboken, Wiley \& Sons.

Nieuwenhuys R (1967): Comparative anatomy of the cerebellum. Prog Brain Res 25:1-93.

Nieuwenhuys R (2011): The development and general morphology of the telencephalon of actinopterygian fishes: synopsis, documentation and commentary. Brain Struct Funct 215: 141-157.

Nieuwenhuys R, Meek J (1990): The telencephalon of actinopterygian fishes; in Jones EG, Peters A (eds): Comparative Structure and Evolution of the Cerebral Cortex. New York, Plenum Press, pp 31-73.

Nisembaum LG, de Pedro N, Delgado MJ, Sánchez-Bretaño A, Isorna E (2014): Orexin as an input of circadian system in goldfish: effects on clock gene expression and locomotor activity rhythms. Peptides 52:29-37.

Nixon JP, Smale L (2007): A comparative analysis of the distribution of immunoreactive orexin $A$ and $B$ in the brains of nocturnal and diurnal rodents. Behav Brain Funct 3:28.

Northcutt RG (1982): Localization of neurons afferent to the optic tectum in longnose gars. J Comp Neurol 204:325-335.

Northcutt RG, Butler AB (1976): Retinofugal pathways in the longnose gar Lepisosteus osseous (Linnaeus). J Comp Neurol 166:1-15.

Northcutt RG, Butler AB (1980): Projections of the optic tectum in the longnose gar, Lepisosteus osseous. Brain Res 190:333-346.

Northcutt RG, Butler AB (1993): The diencephalon and optic tectum of the longnose gar, $\mathrm{Le}$ pisosteus osseus (L.): cytoarchitectonics and distribution of acetylcholinesterase. Brain Behav Evol 41:57-81.

Novak CM, Albers HE (2002): Localization of hypocretin-like immunoreactivity in the brain of the diurnal rodent, Arvicanthis niloticus. J Chem Neuroanat 23:49-58.

Novak CM, Jiang X, Wang C, Teske JA, Kotz CM, Levine JA (2005): Caloric restriction and physical activity in zebrafish (Danio rerio). Neurosci Lett 383:99-104.
Ohkubo T, Boswell T, Lumineau S (2002): Molecular cloning of chicken prepro-orexin cDNA and preferential expression in the chicken hypothalamus. Biochim Biophys Acta 1577:476-480.

Panula P (2010): Hypocretin/orexin in fish physiology with emphasis on zebrafish. Acta Physiol (Oxf) 198:381-386.

Parent A, Northcutt RG (1982): The monoamine-containing neurons in the brain of the garfish, Lepisosteus osseous. Brain Res Bull 9: 189-204.

Pasquier J, Cabau C, Nguyen T, Jouanno E, Severac D, Braasch I, et al: Gene evolution and gene expression after whole genome duplication in fish: the PhyloFish database. BMC Genomics 17:368.

Pasumarthi RK, Fadel J (2008): Activation of orexin/hypocretin projections to basal forebrain and paraventricular thalamus by acute nicotina. Brain Res Bull 77:367-373.

Penney CC, Volkoff H (2014): Peripheral injections of cholecystokinin, apelin, ghrelin and orexin in cavefish (Astyanax fasciatus mexica$n u s)$ : effects on feeding and on the brain expression levels of tyrosine hydroxylase, mechanistic target of rapamycin and appetite-related hormones. Gen Comp Endocrinol 196: 34-40.

Pérez Sirkin DI, Suzuki H, Cánepa MM, Vissio PG (2013): Orexin and neuropeptide Y: tissue specific expression and immunoreactivity in the hypothalamus and preoptic area of the cichlid fish Cichlasoma dimerus. Tissue Cell 45:452-459.

Peyron C, Tighe DK, van den Pol AN, de Lecea L, Heller HC, Sutcliffe JG, Kilduff TS (1998): Neurons containing hypocretin (orexin) project to multiple neuronal systems. J Neurosci 18:9996-10015.

Phillips-Singh D, Li Q, Takeuchi S, Ohkubo T, Sharp PJ, Boswell T (2003): Fasting differentially regulates expression of agouti-related peptide, pro-opiomelanocortin, prepro-orexin, and vasoactive intestinal polypeptide mRNAs in the hypothalamus of Japanese quail. Cell Tissue Res 313:217-225.

Porkka-Heiskanen T, Kalinchuk A, Alanko L, Huhtaniemi I, Stenberg D (2004): Orexin A and $\mathrm{B}$ levels in the hypothalamus of female rats: the effects of the estrous cycle and age. Eur J Endocrinol 150:737-742.

Pu S, Jain MR, Kalra PS, Kalra SP (1998): Orexins, a novel family of hypothalamic neuropeptides, modulate pituitary luteinizing hormone secretion in an ovarian steroid-dependent manner. Regul Pept 78:133-136.

Puelles L, Rubenstein JL (2003): Forebrain gene expression domains and the evolving prosomeric model. Trends Neurosci 26:469-476.

Puelles L, Rubenstein JL (2015): A new scenario of hypothalamic organization: rationale of new hypotheses introduced in the updated prosomeric model. Front Neuroanat 9:27.

Rink E, Wullimann MF (2001): The teleostean (zebrafish) dopaminergic system ascending to the subpallium (striatum) is located in the basal diencephalon (posterior tuberculum). Brain Res 889:316-330.

Rink E, Wullimann MF (2002): Conncetions of the ventral telencephalon and tyrosine hydroxylase distribution in the zebrafish brain (Danio rerio) lead to identification of an ascending dopaminergic system in teleost. Brain Res Bull 57:385-387.

Rink E, Wullimann MF (2004): Connections of the ventral telencephalon (subpallium) in the zebrafish (Danio rerio). Brain Res 1011:206220

Sakurai T, Amemiya A, Ishii M, Matsuzaki I, Chemelli RM, Tanaka H, et al (1998): Orexins and orexin receptors: a family of hypothalamic neuropeptides and $\mathrm{G}$ protein-coupled receptors that regulate feeding behavior. Cell 92: 573-585.

Sakurai T, Mieda M (2011): Connectomics of orexin-producing neurons: Interface of systems of emotion, energy homeostasis and arousal. Trends Pharmacol Sci 32:451-462.

Schmitt O, Usunoff KG, Lazarov NE, Itzev DE, Eipert P, Rolfs A, Wree A (2012): Orexinergic innervation of the extended amygdala and basal ganglia in the rat. Brain Struct Funct 217:233-256.

Seoane LM, Tovar SA, Perez D, Mallo F, Lopez M, Señaris R, Casanueva FF, Dieguez C (2004): Orexin A suppresses in vivo GH secretion. Eur J Endocrinol 150:731-736.

Shahid IZ, Rahman AA, Pilowsky PM (2012): Orexin and central regulation of cardiorespiratory system; in Litwack G (ed): Vitamins and Hormones, vol 89. Burlington, Academic Press, pp 159-184.

Shahjahan M, Kitahashi T, Parhar IS (2014): Central pathways integrating metabolism and reproduction in teleosts. Front Endocrinol 5:36.

Shibahara M, Sakurai T, Nambu T, Takenouchi T, Iwaasa $\mathrm{H}$, Egashira SI, Ihara $\mathrm{M}$, Goto $\mathrm{K}$ (1999): Structure, tissue distribution, and pharmacological characterization of Xenopus orexins. Peptides 20:1169-1176.

Shibata M, Mondal MS, Date Y, Nakazato M, Suzuki H, Ueta Y (2008): Distribution of orexins-containing fibers and contents of orexins in the rat olfactory bulb. Neurosci Res 61:99_ 105.

Shih CD, Chuang YC (2007): Nitric oxide and GABA mediate bi-directional cardiovascular effects of orexin in the nucleus tractus solitarii of rats. Neuroscience 149:625-635.

Singletary KG, Delville Y, Farrell WJ, Wilczynski W (2005): Distribution of orexin/hypocretin immunoreactivity in the nervous system of the green treefrog, Hyla cinerea. Brain Res 1041:231-236.

Singletary KG, Deviche P, Strand C, Delville Y (2006): Distribution of orexin/hypocretin immunoreactivity in the brain of a male songbird, the house finch, Carpodacus mexicanus. J Chem Neuroanat 32:81-89.

Smith PM, Connolly BC, Ferguson AV (2002): Microinjection of orexin into the rat nucleus tractus solitarius causes increases in blood pressure. Brain Res 950:261-267. 
Song JK, Northcutt RG (1991a): Morphology, distribution and innervation of the lateral-line receptors of the Florida gar, Lepisosteus platyrhincus. Brain Behav Evol 37:10-37.

Song JK, Northcutt RG (1991b): The primary projections of the lateral-line nerves of the Florida gar, Lepisosteus platyrhincus. Brain Behav Evol 37:38-63.

Stanley BG, Willett III VL, Donias HW, Dee II MG, Duva MA (1996): Lateral hypothalamic NMDA receptors and glutamate as physiological mediators of eating and weight control. Am J Physiol 270:R443-R449.

Sternberger LA (1979): The unlabeled antibody (PAP) method, introduction. J Histochem Cytochem 27:1657.

Stiassny MLJ, Wiley EO, Johnson DG, de Carvalho MR (2004): Gnathostome fishes; in Cracraft J, Donoghue MJ (eds): Assembling the Tree of Life. New York, Oxford University Press, pp 419-429.

Straka H, Baker R, Gilland E (2006): Preservation of segmental hindbrain organization in adult frogs. J Comp Neurol 494:228-245.

Suzuki H, Matsumoto A, Yamamoto T (2009): Orexin-B-like immunoreactivity localized in both luteinizing hormone- and thyroid-stimulating hormone-containing cells in the Nile tilapia (Oreochromis niloticus) pituitary. Tissue Cell 41:75-78.

Suzuki H, Takemoto Y, Yamamoto (2007): Differential distribution of orexin-A-like and orexin receptor 1 (OXR1)-like immunoreactivities in the Xenopus pituitary. Tissue Cell 39:423-430.

Suzuki H, Yamamoto T (2013): Orexin-B-like immunoreactivity localizes in both luteinizinghormone-containing cells and melanin-concentrating hormone-containing fibers in the red-bellied piranha (Pygocentrus nattereri) pituitary. Cell Tissue Res 351:175-182.

Tam JK, Lau KW, Lee LT, Chu JY, Ng KM, Fournier A, Vaudry H, Chow BK (2011): Origin of secretin receptors precedes the advent of tetrapoda: evidence in the separated origins of secretin and orexin. PLoS One 6:e19384.

Ten Donkelaar HJ (1998): Reptiles; in Nieuwenhuys R, Ten Donkelaar HJ, Nicholson C (eds): The Central Nervous System of Vertebrates, vol 2. Berlin, Springer, pp 1315-1524.
Teske JA, Billington CJ, Kotz CM (2010): Hypocretin/orexin and energy expenditure. Acta Physiol 198:303-312.

van den Pol AN (1999): Hypothalamic hypocretin (orexin): robust innervation of the spinal cord. J Neurosci 19:3171-3182.

Vittoz NM, Schmeichel B, Berridge CW (2008): Hypocretin/orexin preferentially activates caudomedial ventral tegmental area dopamine neurons. Eur J Neurosci 28:1629-1640.

Volkoff H (2006): The role of neuropeptide Y, orexins, cocaine and amphetamine-related transcript, cholecystokinin, amylin and leptin in the regulation of feeding in fish. Comp Biochem Physiol A Mol Integr Physiol 144:325331.

Volkoff H (2012): Sleep and orexins in nonmammalian vertebrates. Vitam Horm 89:315-39.

Volkoff H, Bjorklund JM, Peter RE (1999): Stimulation of feeding behavior and food consumption in the goldfish, Carassius auratus, by orexin-A and orexin-B. Brain Res 846: 204-209.

Volkoff H, Canosa LF, Unniappan S, Cerda-Reverter JM, Bernier NJ, Kelly SP, Peter RE (2005): Neuropeptides and the control of food intake in fish. Gen Comp Endocrinol 142:319.

Volkoff H, Eykelbosh AJ, Peter RE (2003): Role of leptin in the control of feeding of goldfish Carassius auratus: interactions with cholecystokinin, neuropeptide $\mathrm{Y}$ and orexin $\mathrm{A}$, and modulation by fasting. Brain Res 972:90-109.

Volkoff H, Peter RE (2001): Interactions between orexin A, NPY and galanin in the control of food intake of the goldfish, Carassius auratus. Regul Pept 101:59-72.

Wang QP, Guan JL, Matsuoka T, Hirayana Y, Shioda S (2003): Electron microscopic examination of the orexin immunoreactivity in the dorsal raphe nucleus. Peptides 24:925-930.

Winn P, Tarbuck A, Dunnett SB (1984): Ibotenic acid lesions of the lateral hypothalamus: comparison with the electrolytic lesion syndrome. Neuroscience 12:225-240.

Wong KK, Ng SY, Lee LT, Ng HK, Chow BK (2011): Orexins and their receptors from fish to mammals: a comparative approach. Gen Comp Endocrinol 171:124-130.
Wu M, Zaborszky L, Hajszan T, van den Pol AN, Alreja M (2004): Hypocretin/orexin innervation and excitation of identified septohippocampal cholinergic neurons. J Neurosci 24: 3527-3536.

Wu M, Zhang Z, Leranth C, Xu C, van den Pol AN, Alreja (2002): Hypocretin increases impulse flow in the septohippocampal GABAergic pathway: implications for arousal via a mechanism of hippocampal disinhibition. J Neurosci 22:7754-7765.

Yamamoto K, Bloch S, Vernier P (2017): New perspective on the regionalization of the anterior forebrain in Osteichthyes. Dev Growth Differ 59:175-187.

Yamamoto N, Ishikawa Y, Yoshimoto M, Xue HG, Bahaxar N, Sawai N, et al (2007): A new interpretation on the homology of the teleostean telencephalon based on hodology and a new eversion model. Brain Behav Evol 69:96104.

Yamamoto T, Suzuki H, Uemura H, Yamamoto K, Kikuyama S (2004): Localization of orexinA-like immunoreactivity in prolactin cells in the bullfrog (Rana catesbeiana) pituitary. Gen Comp Endocrinol 135:186-192.

Yamanaka A, Kunii K, Nambu T, Tsujino N, Sakai A, Matsuzaki I, et al (2000): Orexin-induced food intake involves neuropeptide $\mathrm{Y}$ pathway. Brain Res 859:404-409.

Yokobori E, Azuma M, Nishiguchi R, Kang KS, Kamijo M, Uchiyama M, Matsuda K (2012): Neuropeptide Y stimulates food intake in the zebrafish, Danio rerio. J Neuroendocrinol 24: 766-773.

Yokogawa T, Marin W, Faraco J, Pézeron G, Appelbaum L, Zhang J, et al (2007): Characterization of sleep in zebrafish and insomnia in hypocretin receptor mutants. PLoS Biol 5: e277.

Yoshida K, McCormack S, España RA, Crocker A, Scammell TE (2006): Afferents to the orexin neurons of the rat brain. J Comp Neurol 494: 845-861.

Zhang JH, Sampogna S, Morales FR, Chase MH (2001): Orexin (hypocretin)-like immunoreactivity in the cat hypothalamus: a light and electron microscopic study. Sleep 24:67-76.

Zhang JH, Sampogna S, Morales FR, Chase MH (2004): Distribution of hypocretin (orexin) immunoreactivity in the feline pons and medulla. Brain Res 995:205-217. 